\title{
THE
}

\section{The Deep Convective Clouds and Chemistry (DC3) Field Campaign}

\author{
Mary C. Barth \\ Brian G. Heikes \\ University of Rhode Island, bheikes@uri.edu \\ et al
}

Follow this and additional works at: https://digitalcommons.uri.edu/gsofacpubs

\section{Citation/Publisher Attribution}

Barth, M. C., Cantrell, C. A., Brune, W. H., Rutledge, S. A., Crawford, J. H., Huntriesser, H., Carey, L. D.,...Ziegler, C. (2015). The Deep Convective Clouds and Chemistry (DC3) Field Campaign. Bull. Amer. Meteor. Soc., 96, 1281-1309. doi: 10.1175/BAMS-D-13-00290.1

Available at: http://dx.doi.org/10.1175/BAMS-D-13-00290.1

This Article is brought to you for free and open access by the Graduate School of Oceanography at DigitalCommons@URI. It has been accepted for inclusion in Graduate School of Oceanography Faculty Publications by an authorized administrator of DigitalCommons@URI. For more information, please contact digitalcommons-group@uri.edu. 


\section{THE DEEP CONVECTIVE CLOUDS AND CHEMISTRY (DC3) FIELD CAMPAIGN}

by Mary C. Barth, Christopher A. Cantrell, William H. Brune, Steven A. Rutledge, James H. Crawford, Heidi Huntrieser, Lawrence D. Carey, Donald MacGorman, Morris Weisman, Kenneth E. Pickering, Eric Bruning, Bruce Anderson, Eric Apel, Michael Biggerstaff, Teresa Campos,

Pedro Campuzano-Jost, Ronald Cohen, John Crounse, Douglas A. Day, Glenn Diskin, Frank Flocke, Alan Fried, Charity Garland, Brian Heikes, Shawn Honomichl, Rebecca Hornbrook, L. Gregory Huey, Jose L. Jimenez, Timothy Lang, Michael Lichtenstern, Tomas Mikoviny, Benjamin Nault, Daniel O’Sullivan, Laura L. Pan, Jeff Peischl, Ilana Pollack, Dirk Richter, Daniel Riemer, Thomas Ryerson, Hans Schlager, Jason St. Clair, James Walega, Petter Weibring, Andrew Weinheimer, Paul Wennberg, Armin Wisthaler, Paul J.Wooldridge, and Conrad Ziegler

DC3 brought together simultaneous measurements of storm kinematics, structure, electrical activity, and chemistry to improve our knowledge of how thunderstorms affect the chemical composition of the troposphere.

$\mathrm{T}$ hunderstorms over the central United States are a near-daily occurrence during the late spring and summer (e.g., Carbone et al. 2002). These storms range from airmass thunderstorms, to multicellular thunderstorms and supercells, to mesoscale convective systems (MCSs) depending on the instability, wind shear, and mesoscale forcing of the atmosphere. Many studies on thunderstorms have been concerned with predicting precipitation and severity of the storms for human welfare as well as understanding the formation of hail and lightning. However, convective storms can also have a widespread impact on upper-tropospheric (UT) composition over the United States and downwind over the western North Atlantic as discovered by previous field campaigns (e.g., Dickerson et al. 1987; Dye et al. 2000; Brunner et al. 1998; Crawford et al. 2000; Cooper et al. 2006; Bertram et al. 2007) and modeling studies (e.g., Chatfield and Crutzen 1984; Zhang et al. 2003; Li et al. 2005; Allen et al. 2010; Barth et al. 2012).
As trace gases and aerosols are transported from the boundary layer (BL) to the UT, several processes occur along the way affecting the constituents' abundance. The redistribution of reactive chemical species by convective transport were theoretically recognized by Chatfield and Crutzen (1984) and observed for ozone $\left(\mathrm{O}_{3}\right)$, nitric oxide (NO), carbon monoxide (CO), and volatile organic compounds (VOCs) by Dickerson et al. (1987). Convective storms were also found to rain out highly soluble trace gases [e.g., nitric acid $\left.\left(\mathrm{HNO}_{3}\right)\right]$ and hygroscopic aerosols (e.g., sulfate), while lightning was found to produce substantial amounts of nitrogen oxides $\left(\mathrm{NO}_{x}=\mathrm{NO}+\mathrm{NO}_{2}\right.$; e.g., Ridley et al. 1994, 2004b). Estimating the convective transport and scavenging of partially soluble trace gases [e.g., formaldehyde $\left(\mathrm{CH}_{2} \mathrm{O}\right)$, hydrogen peroxide $\left(\mathrm{H}_{2} \mathrm{O}_{2}\right)$, and methyl hydroperoxide $\left.\left(\mathrm{CH}_{3} \mathrm{OOH}\right)\right]$ that are precursors for hydrogen oxides $\left(\mathrm{HO}_{x}=\mathrm{OH}+\right.$ $\mathrm{HO}_{2}$ ) and $\mathrm{O}_{3}$ has proven to be challenging. The role of ice in the convective processing of these soluble 
trace gases is poorly understood (Barth et al. 2001, 2007a), while scattering of sunlight by cloud particles complicates photochemistry that occurs within and near the storm. UT trace gases affected by convective transport and lightning then undergo photochemistry, increasing ozone production in the UT by as much as a factor of 4 with peak net ozone production rates of 15 ppbv day ${ }^{-1}$ as estimated by modeling studies (Pickering et al. 1990).

While several studies in the past 20 years have explored the influence of deep convection on the chemical composition of the upper troposphere (e.g., Pickering et al. 1996; Jaeglé et al. 1997; Ridley et al. 2004a,b; Singh et al. 2007; Huntrieser et al. 2002, 2007, 2008, 2009, 2011; Ancellet et al. 2009; Barret et al. 2010; Avery et al. 2010), there has not been a field experiment providing a comprehensive suite of airborne chemical composition measurements within the context of ground-based storm kinematic, microphysical, and lightning observations. In addition, none of these previous field experiments intentionally investigated the photochemical aging of the UT convective outflow by tracking the convective outflow from the thunderstorm to regions downwind.

The Deep Convective Clouds and Chemistry (DC3) field campaign utilized extensively instrumented aircraft platforms and ground-based observations to investigate the impact of deep, midlatitude continental convective clouds, including their dynamical, physical, and lightning processes, on UT composition and chemistry. The DC3 field campaign had two major goals:
1) quantify and characterize the convective transport of emissions and water to the upper troposphere within the first few hours of active convection, investigating storm dynamics and physics, lightning and its production of nitrogen oxides, cloud hydrometeor effects on scavenging of species, surface emission variability, and chemistry in the anvil, and

2) quantify the changes in chemistry and composition in the upper troposphere after active convection, focusing on 12-48 $\mathrm{h}$ after convection and the seasonal transition of the chemical composition of the UT.

Context with previous studies. Findings from previous studies of thunderstorms and chemistry motivated many of the DC3 objectives. Highlighted results from these previous campaigns are discussed here.

The 1996 Stratosphere-Troposphere Experiment: Radiation, Aerosols, and Ozone (STERAO-A) campaign, which sampled storms in northeast Colorado, used two aircraft, the University of North Dakota Citation and the National Oceanic and Atmospheric Administration (NOAA) P-3D, to sample the composition in the inflow and outflow regions of the storms. The Colorado State University (CSU)-University of Chicago-Illinois State Water Survey (CHILL) national radar facility and the Office National d'Etudes et Recherches Aérospatiales (ONERA) lightning interferometer array sampled storm kinematics and lightning, respectively. A detailed examination of the 10 and 12 July 1996 STERAO storms revealed that 1) intracloud (IC) lightning flashes can be a major
Affiliations: Barth, Weisman, Apel, Campos, Flocke, Honomichl, Hornbrook, PAN, ANd Weinheimer-NCAR,* Boulder, Colorado; Cantrell, Campuzano-Jost, Day, Fried, Jimenez, Richter, Walega, and WeIBrING-University of Colorado, Boulder, Colorado; BRUNEThe Pennsylvania State University, University Park, Pennsylvania; RutLedge AND LANG ${ }^{+}$—Colorado State University, Ft. Collins, Colorado; Crawford, ANDERSON, AND DISKIN-NASA Langley Research Center, Hampton, Virginia; HUNTRIESER, LICHTENSTERN, AND SCHLAGER-Deutsches Zentrum für Luft- und Raumfahrt (DLR), Oberpfaffenhofen, Germany; CAREY-University of Alabama in Huntsville, Huntsville, Alabama; MacGorman ANd ZIEGLer-NOAA/ NSSL, Norman, Oklahoma; PICKERING—NASA Goddard Space Flight Center, Greenbelt, Maryland; BRUNING-Texas Tech University, Lubbock, Texas; BIgGerSTAFF-University of Oklahoma, Norman, Oklahoma; Cohen, Garland, NAUlt, AND Wooldridge-University of California, Berkeley, Berkeley, California; CrounSE, ST. CLAIR, AND WenNBERG-California Institute of Technology, Pasadena, California; HEIKES-School of Oceanography, University of Rhode Island, Narragansett, Rhode Island; HUEY-Georgia Institute of Technology,
Atlanta, Georgia; MıKovinY-Oak Ridge Associated Universities, Oak Ridge, Tennessee; O'Sullivan-United States Naval Academy, Annapolis, Maryland; PeISCHL, POLLACK, ANd RYERSON-NOAA/ESRL, Boulder, Colorado; RIEMER-University of Miami, Coral Gables, Florida; WISTHALER - Institut für lonenphysik und Angewandte Physik, Innsbruck, Austria

*The National Center for Atmospheric Research is sponsored by the National Science Foundation +CURRENT AFFILIATION: NASA Marshall Space Flight Center, Huntsville, Alabama CORRESPONDING AUTHOR: Mary C. Barth, NCAR, P.O. Box 3000, Boulder, CO 80307

E-mail: barthm@ucar.edu

The abstract for this article can be found in this issue, following the table of contents.

DOI:I0.II75/BAMS-D-I3-00290.I

In final form 5 November 2014

(C2015 American Meteorological Society 


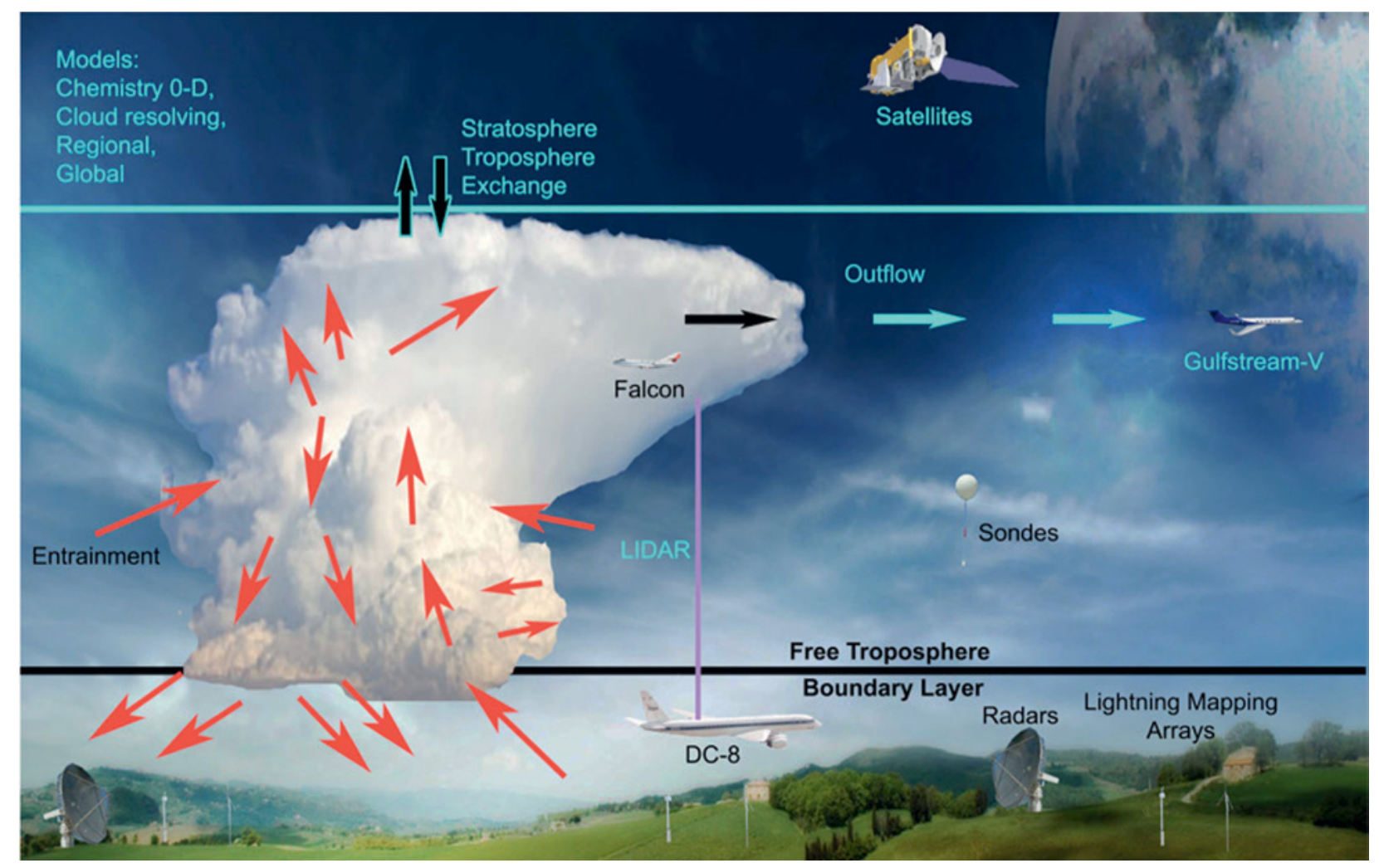

Fig. I. Schematic of the DC3 experiment strategy for observing thunderstorms.

contributor to $\mathrm{NO}_{x}$ [DeCaria et al. (2000); as opposed to earlier studies that claimed that $\mathrm{NO}_{x}$ production per IC flash was $10 \%$ of the $\mathrm{NO}_{x}$ production from a cloud-to-ground (CG) flash], 2) lightning occurred primarily in moderate updrafts and weak downdrafts (Dye et al. 2000), 3) production of NO from lightning was estimated to be $330-460 \mathrm{~mol} \mathrm{NO}(4.6-6.5 \mathrm{~kg} \mathrm{~N})$ per flash (DeCaria et al. 2005), and 4) cloud-scale modeling reasonably represented transport and redistribution of insoluble trace gases, but it was unknown how well they represented transport and scavenging of soluble gases (Barth et al. 2007b). Therefore, an objective of DC3 was to learn how much of the soluble trace gases that are precursors for $\mathrm{O}_{3}$ production is transported to the UT in thunderstorms.

Two results from the 2000 Severe Thunderstorm Electrification and Precipitation Study (STEPS), which sampled storm and lightning characteristics in the high plains region of eastern Colorado and western Kansas by the first-generation lightning mapping array (LMA), polarimetric radar, storm-penetrating aircraft, and electric field meter soundings (Lang et al. 2004) motivated additional observations. Wiens et al. (2005) related storm parameters to total lightning flash rates rather than to only CG flash rates. Via modeling of a supercell, Kuhlman et al. (2006) found that trends in total flash rates were well correlated with trends in ice mass flux, volumes of updrafts greater than $10 \mathrm{~m} \mathrm{~s}^{-1}$, and the volume of graupel. Thus, one objective of DC3 was to evaluate these and other relationships between lightning and storm properties for storms observed in a variety of regions. A second result from STEPS was the discovery that polarity of the charge distribution in the vertical was inverted from the polarity usually observed outside the high plains, with a large region of positive charge at midlevel and a large region of negative charge at upper levels (Rust and MacGorman 2002; Rust et al. 2005; MacGorman et al. 2005; Wiens et al. 2005; Tessendorf et al. 2007; Weiss et al. 2008; Bruning et al. 2014). Many of these storms produced predominantly positive CG flashes and were characterized as low-precipitation storms. In a statistical study of many storms, MacGorman et al. (2011) reported that storms observed during STEPS tended to require tens of minutes longer to produce a CG flash after producing their first flash than storms required outside the high plains and suggested that this delay was caused by the longer time needed to develop precipitation in the lower region of the storm. A better understanding of inverted-polarity storms was an objective of DC3 because they produce a larger-than-usual fraction of cloud lightning at higher altitudes, thereby impacting the vertical placement of lightning- $\mathrm{NO}_{x}$ sources. 


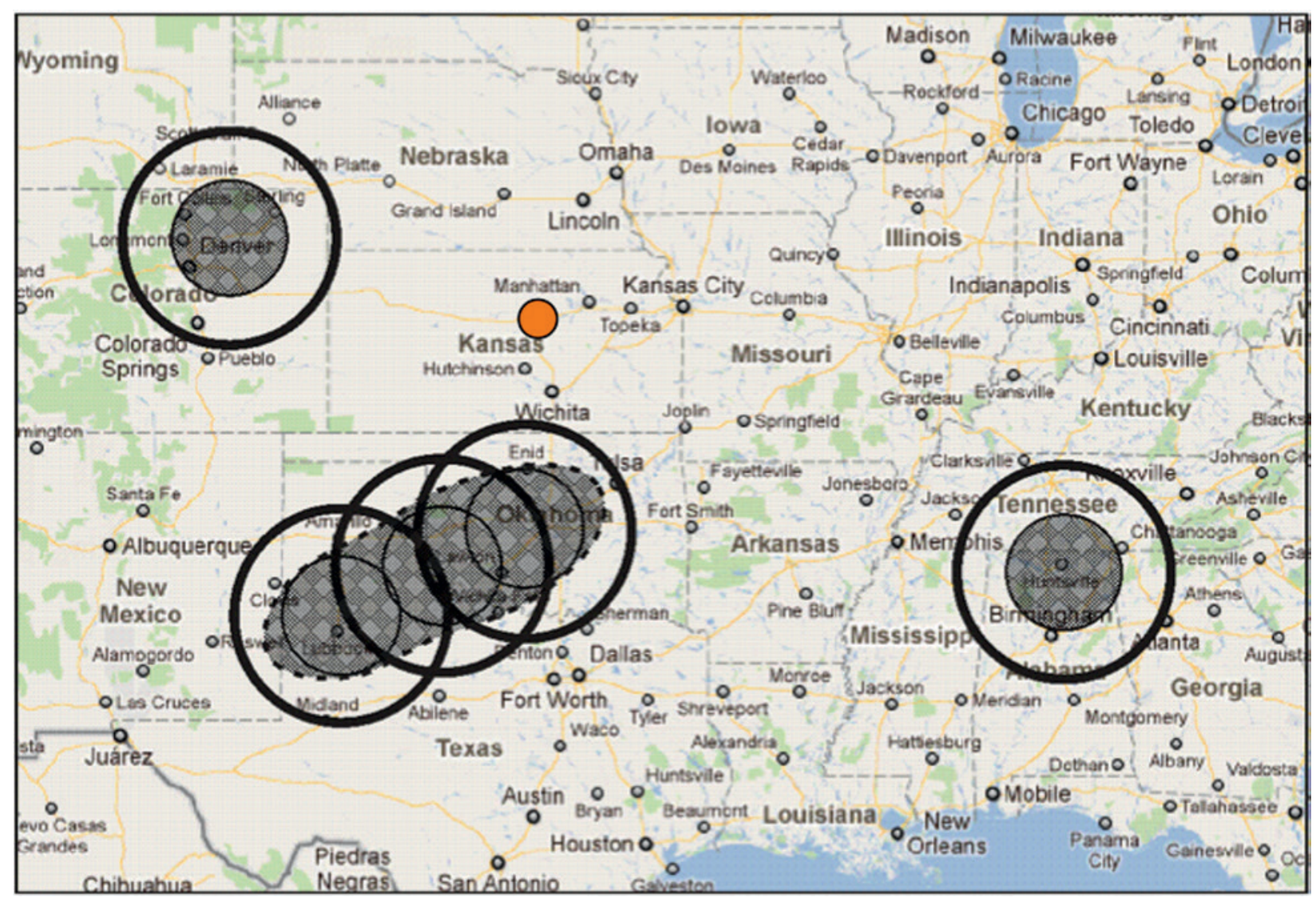

FIG. 2. Locations of the three sampling regions. The orange dot marks Salina, KS, where the DC3 operations center was located. The shaded regions denote the range from each lightning mapping array that the VHF sources can be located in three-dimensional space, while the black circles show the region where VHF sources can be located in two-dimensional space.

The Intercontinental Chemical Transport Experiment Phase A (INTEX-A) campaign used the National Aeronautics and Space Administration (NASA) DC-8 aircraft to sample the atmospheric composition over North America during July and August 2004. The results from INTEX-A showed a substantial influence of deep convection on UT composition. Bertram et al. (2007) estimated that $54 \%$ of UT air was influenced by convection that occurred during the previous 2 days. Snow et al. (2007) showed that convectively influenced air was enhanced in $\mathrm{CH}_{3} \mathrm{OOH}, \mathrm{CH}_{2} \mathrm{O}, \mathrm{CO}, \mathrm{NO}$, and $\mathrm{NO}_{2}$ and depleted in $\mathrm{H}_{2} \mathrm{O}_{2}$ and $\mathrm{HNO}_{3}$ compared to the background UT atmosphere. Singh et al. (2007) and Hudman et al. $(2007,2009)$ found that the influence of lightning on $\mathrm{NO}_{x}$ in the UT was approximately 4 times greater than expected by global models. These intriguing results from INTEX-A motivate further research to understand the storm processes affecting convective transport of trace gases, to better follow the chemical evolution of UT convective outflow to quantify $\mathrm{O}_{3}$ production, and to examine the vertical extent of the impact by convection on the UT composition. These were all objectives of DC3.

The African Monsoon Multidisciplinary Analysis (AMMA) campaign in 2006 in western Africa used several aircraft (French Falcon, French ATR-42, German DLR Falcon, UK BAe-146) to sample the composition of the BL and UT near convective storms, while radars sampled the storm structure and kinematics, and the very low-frequency/low-frequency lightning detection network (LINET) detected lightning flashes. Huntrieser et al. (2011) studied two mesoscale convective systems and determined the production of NO from lightning to be 70-180 mol NO per flash. These lightning- $\mathrm{NO}_{x}$ production estimates are similar to findings from other tropical studies but smaller than the 300-500 mol per flash estimated for midlatitude storms (Schumann and Huntrieser 2007). Note that $100 \mathrm{~mol} \mathrm{NO}$ is equivalent to $3 \mathrm{~kg} \mathrm{NO}$ or $1.4 \mathrm{~kg} \mathrm{~N}$. This significant difference of $\mathrm{LNO}_{x}$ production between the midlatitudes and tropics calls for better understanding of the storm processes affecting $\mathrm{LNO}_{x}$ production and exploring whether other flash characteristics (e.g., 


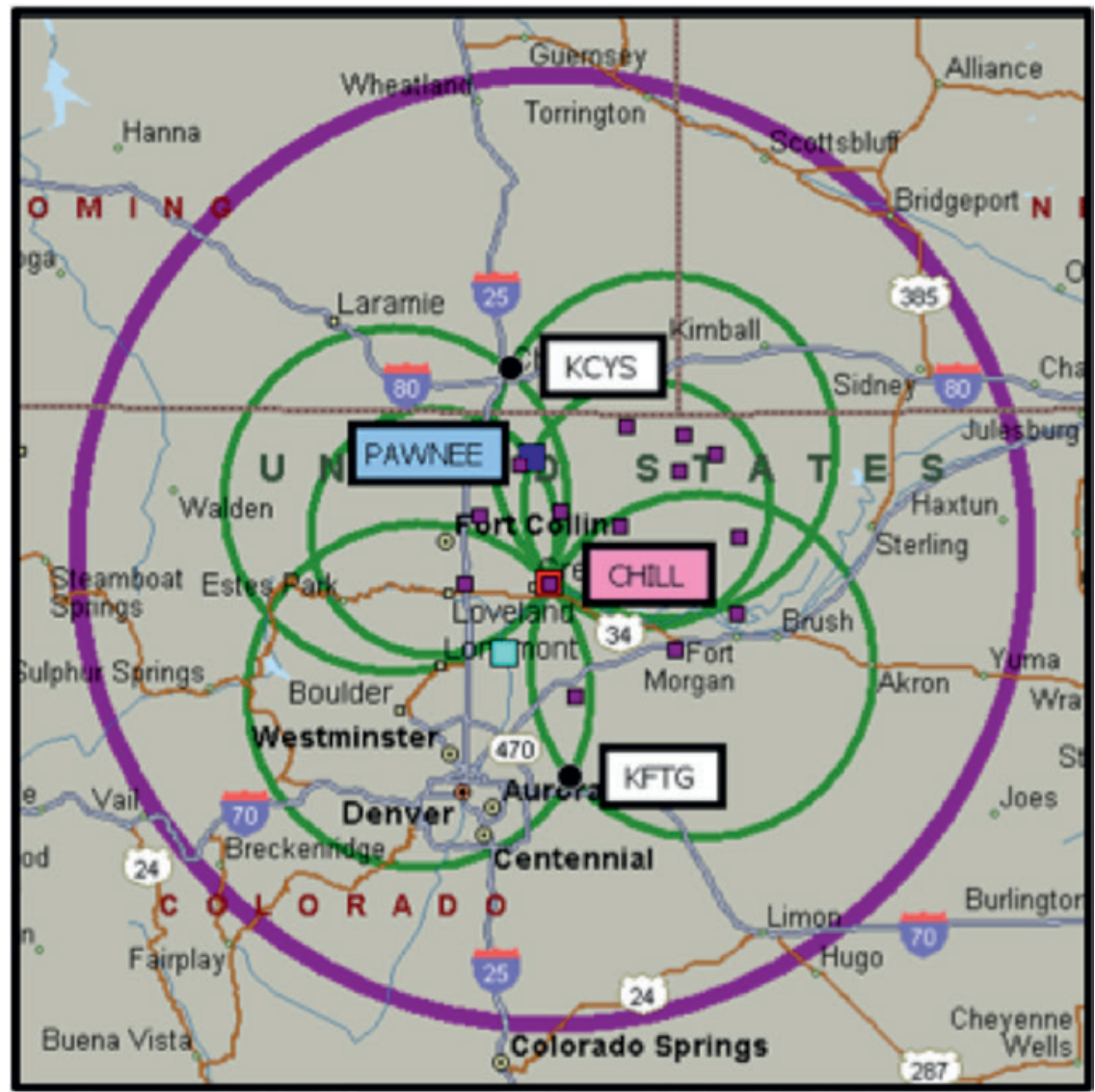

FIG. 3. The Colorado ground network configuration. The radars are CSUCHILL (red square), CSU-Pawnee (blue square), and National Weather Service (NWS) (black squares). The purple square dots locate the LMA stations. The purple circle denotes the LMA coverage with $300-\mathrm{m}$ location error. The green circles are the dual-Doppler and polarimetric radar coverage. in the outflow region of the storm. After characterizing the $\mathrm{BL}$, the $\mathrm{DC}-8$ aircraft often ascended to the anvil and sampled the outflow region to connect inflow and outflow for the variables measured aboard the DC- 8 that were not sampled by the other aircraft (primarily aerosol properties and $\mathrm{HO} x$ mixing ratios). The DLR Falcon aircraft sampled the outflow region-however, closer to the convective core and frequently separated in time (few hours) and space (other cells of a larger convective system) compared to the storms investigated by the GV and DC-8.

Storms in three regions (Fig. 2)-northeast Colorado, central Oklahoma to west Texas, and northern Alabamawere sampled by aircraft deployed from an operations base in Salina, Kansas. The sampling regions were chosen because 1) they all have ample ground-based flash extent) contribute to the $\mathrm{LNO}_{x}$ production. Such information is vital for refining estimates for the global production of NO from lightning, which is currently accepted to be $5 \pm 3 \mathrm{Tg} \mathrm{N}$ annually (Schumann and Huntrieser 2007).

EXPERIMENTAL DESIGN. Overall experimental design. To address the first DC3 goal of characterizing the impact of deep convective storms on the chemical environment, aircraft were deployed to sample trace gases, aerosols, and meteorological properties in the inflow and outflow regions of the thunderstorms (Fig. 1). Ground-based radar networks, LMAs, and weather balloons obtained data on storm kinematics and structure, lightning, and storm thermodynamic environment. When multiple aircraft were sampling one storm, one aircraft, usually the NASA DC-8, was placed in the inflow region, while the second, usually the National Center for Atmospheric Research (NCAR) Gulfstream V (GV) aircraft, was placed facilities, 2) the likelihood of convection occurring in one of the three locations increases the chances of successful flight operations on any given day, and 3) the three regions have different storm properties and chemical composition environments. The DC3 principal investigators' (PIs') goal was to have four cases sampled by aircraft in each of the three regions, thus allowing an even distribution of different storm properties and chemical environments for analysis. Details describing the three regions are given below.

To determine the probability of thunderstorms at each sampling region and to predict the location of the UT convective outflow plume $12-48 \mathrm{~h}$ after active convection, several high-resolution Weather Research and Forecasting (WRF) Model forecasts were conducted. The NCAR research-grade 48 -h WRF forecasts at $3-\mathrm{km}$ UTC), with the initial conditions supplied by a continuously cycling ensemble Kalman filter analysis-forecast system with $15-\mathrm{km}$ horizontal grid length, using the grid spacing were produced twice a day (0000 and 1200 


\begin{tabular}{|c|c|}
\hline Radar & Detects \\
\hline \multicolumn{2}{|r|}{ Colorado } \\
\hline CSU-CHILL S band & $\begin{array}{l}\text { Precipitating particles, Doppler velocity, clear air returns, and hydrometeor identification } \\
\text { (i.e., polarimetric) }\end{array}$ \\
\hline CSU-Pawnee S band & $\begin{array}{l}\text { Precipitating particles, Doppler velocity, clear air returns, and hydrometeor identification } \\
\text { (i.e., polarimetric) }\end{array}$ \\
\hline NWSWSR-88D KFTG & Reflectivity of precipitating particles and Doppler velocity \\
\hline NWSWSR-88D KCYS & Reflectivity of precipitating particles and Doppler velocity \\
\hline \multicolumn{2}{|r|}{ Oklahoma-Texas } \\
\hline NOAA MPAR S band & Reflectivity of precipitating particles and Doppler velocity \\
\hline NOAA NOXP $X$ band & $\begin{array}{l}\text { Precipitating particles, Doppler velocity, clear air returns, and hydrometeor identification } \\
\text { (i.e., polarimetric) }\end{array}$ \\
\hline OU SMART I C band & Reflectivity of precipitating particles and Doppler velocity \\
\hline OU SMART $2 \mathrm{C}$ band & $\begin{array}{l}\text { Precipitating particles, Doppler velocity, clear air returns, and hydrometeor identification } \\
\text { (i.e., polarimetric) }\end{array}$ \\
\hline OU KOUN S band & $\begin{array}{l}\text { Precipitating particles, Doppler velocity, clear air returns, and hydrometeor identification } \\
\text { (i.e., polarimetric) }\end{array}$ \\
\hline NWSWSR-88D KTLX & Reflectivity of precipitating particles and Doppler velocity \\
\hline NWSWSR-88D KFDR & Reflectivity of precipitating particles and Doppler velocity \\
\hline NWSWSR-88D KLBB & Reflectivity of precipitating particles and Doppler velocity \\
\hline NWSWSR-88D KAMA & $\begin{array}{l}\text { Precipitating particles, Doppler velocity, clear air returns, and hydrometeor identification } \\
\text { (i.e., polarimetric) }\end{array}$ \\
\hline NWSWSR-88D KVNX & $\begin{array}{l}\text { Precipitating particles, Doppler velocity, clear air returns, and hydrometeor identification } \\
\text { (i.e., polarimetric) }\end{array}$ \\
\hline \multicolumn{2}{|r|}{ Alabama } \\
\hline UAH ARMOR C band & $\begin{array}{l}\text { Precipitating particles, Doppler velocity, clear air returns, and hydrometeor identification } \\
\text { (i.e., polarimetric) }\end{array}$ \\
\hline UAH MAXX band & $\begin{array}{l}\text { Precipitating particles, Doppler velocity, clear air returns, and hydrometeor identification } \\
\text { (i.e., polarimetric) }\end{array}$ \\
\hline NWSWSR-88D KHTX & $\begin{array}{l}\text { Precipitating particles, Doppler velocity, clear air returns, and hydrometeor identification } \\
\text { (i.e., polarimetric) }\end{array}$ \\
\hline
\end{tabular}

single member closest to the ensemble mean for each forecast (Schwartz et al. 2014; Romine et al. 2014). These forecasts included boundary layer and lightning- $\mathrm{NO}_{x}$ tracers to predict the location of the downwind outflow. Twenty-four-hour Flexible Particle (FLEXPART) dispersion model (Stohl et al. 2005) forecasts were performed from the location of the convective outflow air in the UT where the aircraft sampled to identify more precisely the location of the downwind plume $20-24 \mathrm{~h}$ later. To aid finding the downwind plume, high $\mathrm{NO}_{2}$ column densities sampled by the morning overpass of the Global Ozone Monitoring Experiment-2 (GOME-2) satellite instrument were used. The global-scale Model for Ozone and Related Chemical Tracers (MOZART) gases (Emmons et al. 2010), Regional Air Quality Modeling System (Pierce et al. 2007), and FLEXPART gave information on the context of the chemical environment including information on species from biomass burning and long-range transport. A lead forecaster located at the operations base led the weather forecasting for the day's storm activity, but regional forecasters based at CSU, NOAA/National Severe Storms Laboratory (NSSL) and University of Oklahoma (OU), and the University of Alabama in Huntsville (UAH) gave detailed, local forecasts. A probabilistic forecasting system was used to aid the decision process 


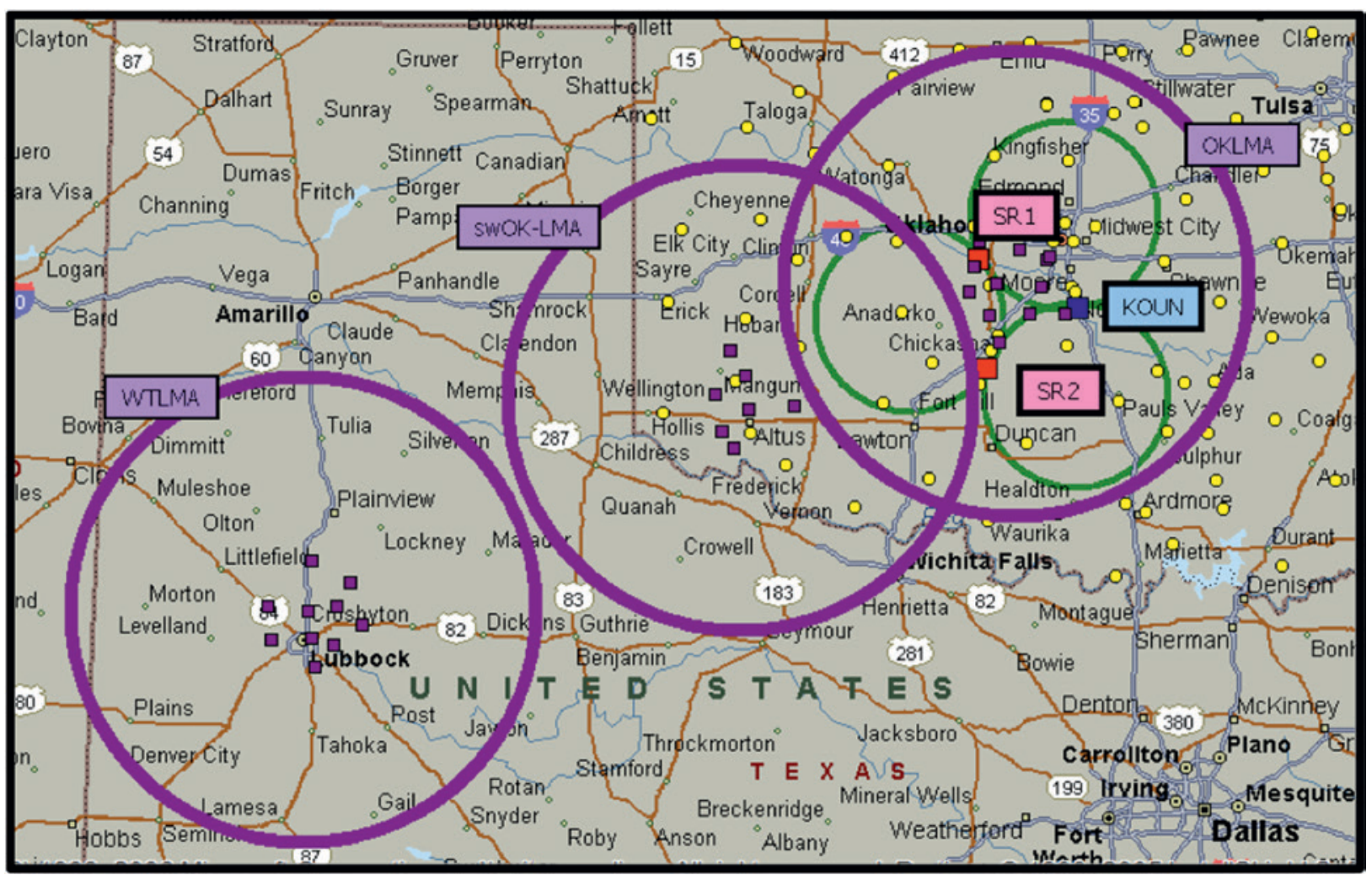

Fig. 4. The Oklahoma-Texas ground network configuration. The red squares are the SMART radars and the blue square is the NWS KOUN radar. The purple squares locate the LMA stations and the yellow dots locate the mesonet stations. The purple circles denote the LMA coverage with $300-\mathrm{m}$ location error. The green circles are the dual-Doppler and polarimetric radar coverage.

for suitable flight conditions and optimum use of flight hours (Hanlon et al. 2014). To ensure the safety of the aircraft, nowcasters at the operations base provided weather updates during flight operations.

We found that the logistical setup worked well for DC3 operations for deploying aircraft to one of three locations. A key part of this success was the centralized operations base where the PIs, lead weather forecaster, and aircraft mission scientists could discuss plans in person. The facilities at Salina were optimal for this, accommodating multiple aircraft and over 200 people in one building. Equally valuable were the Internet-based communications via the field catalog, the tracking of the aircraft and weather during flights, and the aircraft-ground communications that allowed real-time maneuvering as new opportunities appeared. Thus, the preparations for the campaign's physical and computing facilities were crucial.

Colorado. The DC3 northeast Colorado region roughly encompasses the area from Denver, Colorado, to Cheyenne, Wyoming, over the high-elevation plains and foothills of the mountains (Fig. 3). The CSU-CHILL
S-band Doppler and polarimetric radar (Table 1), located in Greeley, Colorado, was the primary radar used in DC3. Located $45 \mathrm{~km}$ to the north is the CSUPawnee S-band radar. These two radars formed a dualDoppler pair providing characterization of 3D winds in precipitation. Two Weather Surveillance Radar-1988 Doppler (WSR-88D) radars-one near Denver and the second in Cheyenne-complemented this dualDoppler pair, extending dual-Doppler coverage from southeastern Wyoming to just south of Denver. The radar data included three-dimensional winds and precipitation and hydrometeor identification fields from CSU-CHILL.

The Colorado lightning mapping array (COLMA; Rison et al. 1999; Lang et al. 2014) consisted of 15 stations detecting very high-frequency (VHF) sources providing lightning locations and lightning channel geometries throughout the region mapped by the dual-Doppler radar pairs. The NCAR Mobile Integrated Sounding System launched radiosondes before and during storms to obtain vertical profiles of environmental temperature, pressure, relative humidity, and winds. 


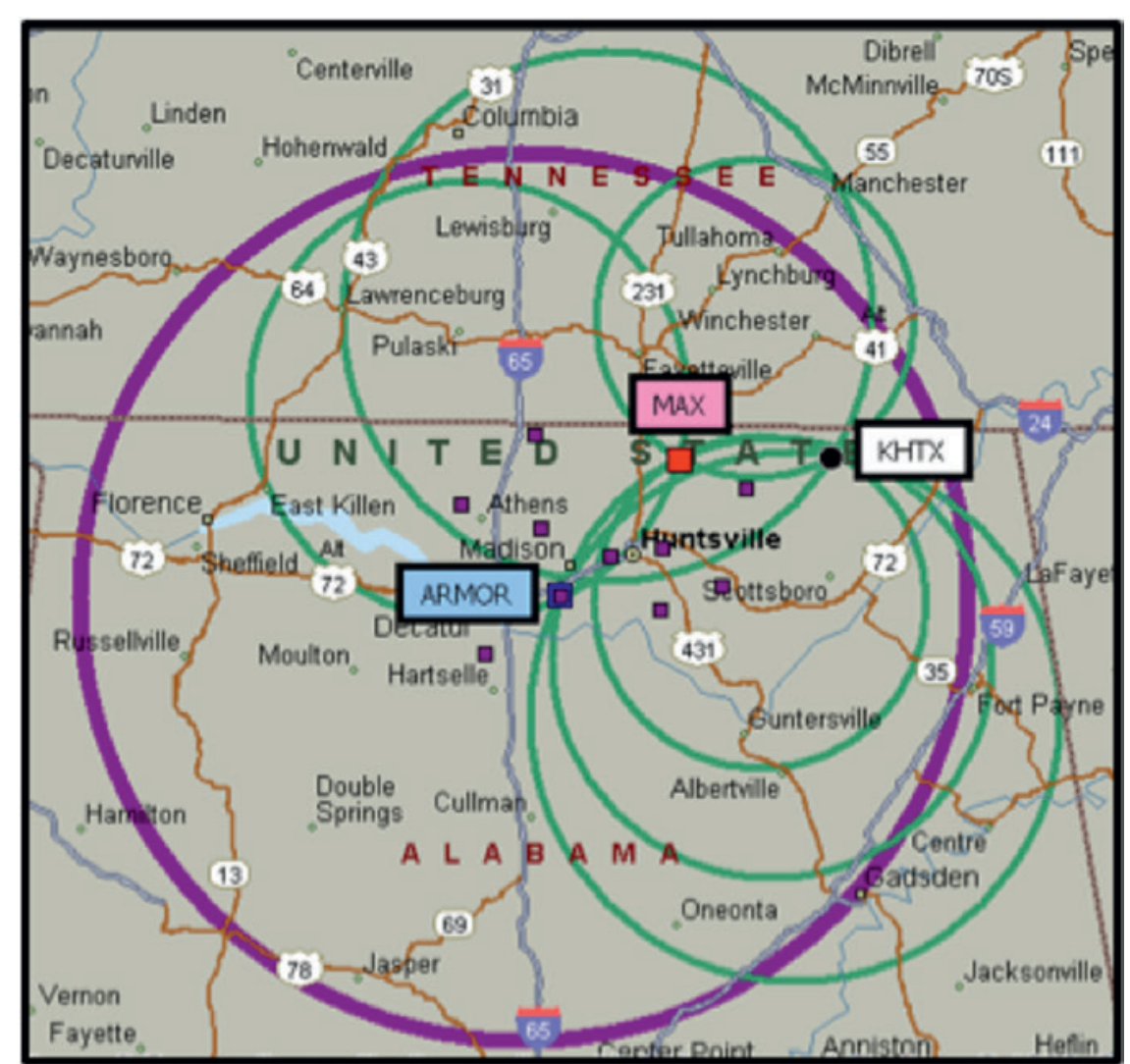

FIG. 5. The Alabama ground network configuration. The radars are the UAH ARMOR and MAX (blue and red squares, respectively) and NWS KHTX (black square). The purple square dots locate the LMA stations. The purple circle denotes the LMA coverage with 300-m location error. The green circles are the dual-Doppler and polarimetric radar coverage.

The Colorado ground-based facilities sampled 16 case studies, including 3 days where electrified fire plumes were studied (Lang et al. 2014). The aircraft sampled storms in northeast Colorado for 8 days. Six of those flights were coordinated with the CSU-CHILL and CSU-Pawnee radars, and two flights, in eastern Colorado, were coordinated with the Oklahoma mobile radars, which are described in the next section.

Oklahoma and Texas. The DC3 central Oklahoma to west Texas region extends from the New Mexico border west of Lubbock, Texas, to northeast of Oklahoma City, Oklahoma (Fig. 4). Radars for the Oklahoma-Texas venue included both fixed site and mobile facilities (Table 1). The fixed radars were the WSR-88D Doppler radars at Oklahoma City, Frederick, and Vance Air Force Base in Oklahoma; Lubbock and Amarillo, Texas; and in Norman, Oklahoma, two $S$-band radars [KOUN and the multifunction phased array radar (MPAR)]. The available mobile radars were the NOAA/NSSL X-band polarimetric (NOXP) radar and the two C-band Shared Mobile Atmospheric Research and Teaching (SMART) radars (SR1 and SR2; Biggerstaff et al. 2005).

The Oklahoma Lightning Mapping Array (OKLMA; MacGorman et al. 2008) includes 11 stations in central Oklahoma and 7 stations in southwest Oklahoma (Fig. 4). The West Texas LMA (WTLMA) has 11 stations near Lubbock. NSSL launched radiosondes before and during storms to obtain vertical profiles of environmental thermodynamic parameters. This system also was used for larger balloons carrying instruments inside storms (Rust et al. 1999) to measure the vector electric field and to provide precipitation imaging along the balloon track.

The Oklahoma radar and sounding units operated on 13 days during the DC3 field campaign. On seven of those days, in-storm electric field measurement soundings were successfully launched into storms. In coordination with the ground facilities, the DC-8 and GV aircraft sampled five cases in the Oklahoma-Texas region, while the Falcon aircraft sampled three additional cases.

Alabama. The DC3 Alabama operations area (Fig. 5) included northern Alabama and southern Tennessee. The ground-based operations included the Advanced Radar for Meteorological and Operational Research (ARMOR) C-band radar, located at the Huntsville International Airport, the truck-based Mobile Alabama X-band (MAX) radar, deployed at a fixed site near New Market, Alabama, $42.5 \mathrm{~km}$ northnortheast of ARMOR, and the WSR-88D Doppler radar, located $34.9 \mathrm{~km}$ east of MAX and $70.3 \mathrm{~km}$ northeast of ARMOR (Table 1). The three radars provide high temporal- and spatial-resolution polarimetric, multi-Doppler observations of storm microphysics and kinematics over the Northern Alabama Lightning Mapping Array (NA-LMA) domain. The NASA Marshall Space Flight Center (MSFC)-owned 


\begin{tabular}{|c|c|c|c|}
\hline Instrument & PI & Species/parameter & Method \\
\hline $\mathrm{O}_{3}$ & CARI $^{\mathrm{b}}$ & $\mathrm{O}_{3}$ & Chemiluminescence \\
\hline $\mathrm{NO}_{x}$ & CARI & $\mathrm{NO}, \mathrm{NO}_{2}$ & Chemiluminescence \\
\hline $\mathrm{CO}$ & CARI & $\mathrm{CO}$ & VUV fluorescence \\
\hline PICARRO & CARI & $\mathrm{CO}_{2}, \mathrm{CH}_{4}$ & CRDS \\
\hline TOGA & Apel & VOCs, OVOCs, halocarbons & GC/MS \\
\hline GTCIMS & Huey & $\mathrm{HNO}_{3}, \mathrm{HNO}_{4}, \mathrm{SO}_{2}, \mathrm{HCl}$ & CIMS \\
\hline P-CIMS & O'Sullivan/Heikes & $\mathrm{H}_{2} \mathrm{O}_{2}, \mathrm{CH}_{3} \mathrm{OOH}$ & CIMS \\
\hline CAMS & Fried & $\mathrm{CH}_{2} \mathrm{O}$ & IR laser spectroscopy \\
\hline HARP & Hall & Actinic flux, spectral irradiance & $\begin{array}{l}\text { Collection, dispersion } \\
\text { spectroscopy }\end{array}$ \\
\hline VCSEL & Zondlo & $\mathrm{H}_{2} \mathrm{O}$ vapor & Laser spectroscopy \\
\hline $\mathrm{CLH}$ & Avallone & $\mathrm{H}_{2} \mathrm{O}$ total & TDL spectroscopy \\
\hline SMPS & Smith/Rogers & Aerosol size distribution $0.0 \mathrm{I}-0.1 \mu \mathrm{m}$ & Particle mobility \\
\hline WCN & RAF $^{\mathrm{c}}$ & Aerosol number & $\begin{array}{l}\text { Optical particle } \\
\text { counter }\end{array}$ \\
\hline UHSAS & RAF & Aerosol size distribution $0.1-1.0 \mu \mathrm{m}$ & Laser optical scattering \\
\hline CDP & RAF & Cloud particle size distribution $2-50 \mu \mathrm{m}$ & Laser optical scattering \\
\hline $2 \mathrm{D}-\mathrm{C}$ & RAF & Cloud particle imager $25-1600 \mu \mathrm{m}$ & Diode array images \\
\hline $3 \mathrm{~V}-\mathrm{CPI}$ & RAF & Cloud particle imager $10-1280 \mu \mathrm{m}$ & $\begin{array}{l}\text { Orthogonal scattering } \\
\text { plus diode array images }\end{array}$ \\
\hline Aircraft & RAF & Basic meteorological and aircraft state data & Various \\
\hline DV & RAF & Video images & Digital cameras \\
\hline
\end{tabular}

${ }^{a}$ A description of the instruments can be found at www-air.larc.nasa.gov/cgi-bin/ArcView/dc3?GV=I.

b The Community Airborne Research Instrumentation (CARI) team is Flocke, Weinheimer, Knapp, Montzka, and Campos.

c RAF is the Research Aviation Facility at NCAR.

and -operated NA-LMA is composed of 11 stations over northern Alabama that are supplemented by two Georgia Institute of Technology sensors located near Atlanta, Georgia (Goodman et al. 2005).

The UAH sounding system launched weather radiosondes in the preconvective, inflow proximity, and postconvective environments on aircraft operations days. The Mobile Integrated Profiling System (MIPS), based at UAH, includes a 915-MHz Doppler wind profiler, $\mathrm{X}$-band profiling radar, microwave profiling radiometer, lidar ceilometer, and a host of standard meteorological sensors to obtain BL and precipitation measurements. MIPS was sometimes deployed to a favored multi-Doppler lobe sampling the preconvective to postconvective environment for constraining the microphysical and kinematic retrievals from the scanning radars.

Twelve cases, including a variety of thunderstorms, were sampled by the ground operations in the northern Alabama region. Two cases were MCSs that occurred at night - a time when aircraft sampling did not occur because of safety considerations. The DC- 8 and GV aircraft sampled two of the Alabama cases in coordination with the ground operations, while the Falcon aircraft did not sample any Alabama storms.

Aircraft. The NCAR GV aircraft sampled storms and aged convective outflow from 18 May to 30 June, while the NASA DC-8 collected data from 18 May to 22 June. The DLR Falcon conducted research flights from 29 May to 14 June. The GV aircraft measured a suite of trace gases, actinic and irradiance fluxes, aerosol number and their size distributions, and cloud water and ice size distributions (Table 2). The DC-8 aircraft sampled many of these same parameters but also measured the aerosol composition and optical properties (Table 3). Unique to the DC-8 aircraft were measurements of the primary oxidants, $\mathrm{OH}$ and 


\begin{tabular}{|c|c|c|c|}
\hline Instrument & $\mathbf{P I}$ & Species/parameter & Method \\
\hline CSD CL & Ryerson & $\mathrm{NO}, \mathrm{NO}_{2}, \mathrm{NO}_{y}, \mathrm{O}_{3}$ & Chemiluminescence \\
\hline TD-LIFc & Cohen & $\mathrm{NO}_{2}, \mathrm{MPN}, \mathrm{PNs}, \mathrm{ANs}$ & TD-LIF \\
\hline DACOM & Diskin & $\mathrm{CO}, \mathrm{CH}_{4}, \mathrm{~N}_{2} \mathrm{O}$ & TDL spectroscopy \\
\hline AVOCET & Beyersdorf & $\mathrm{CO}_{2}$ & Differential NDIR \\
\hline PTR-MS & Wisthaler & VOCs, OVOCs & PTR-MS \\
\hline WAS & Blake & VOCs, OVOCs, halo-VOCs & Canister, GC \\
\hline GTCIMS & Huey & $\mathrm{PAN}, \mathrm{PPN}, \mathrm{HNO}_{4}, \mathrm{SO}_{2}, \mathrm{HCl}$ & CIMS \\
\hline CIT-CIMS & Wennberg & $\begin{array}{l}\mathrm{H}_{2} \mathrm{O}_{2}, \mathrm{CH}_{3} \mathrm{OOH}, \mathrm{HNO}_{3}, \mathrm{C}_{5} \mathrm{H}_{10} \mathrm{O}_{3}, \mathrm{C}_{5} \mathrm{H}_{8} \mathrm{O}_{3} \\
\text { ETHLN, GLYC, HAC, HCN, IEPOX, ISOPN, } \\
\text { ISOPOOH, PAA, PROPNN }\end{array}$ & CIMS \\
\hline DFGAS & Fried & $\mathrm{CH}_{2} \mathrm{O}$ & IR laser spectroscopy \\
\hline ISAF & Hanisco & $\mathrm{CH}_{2} \mathrm{O}$ & LIF \\
\hline SAGA & Dibb, Weber & $\mathrm{HNO}_{3}$, fine-particle $\mathrm{SO}_{4}$, brown carbon & MC/IC, filters \\
\hline ATHOS & Brune & $\mathrm{OH}, \mathrm{HO}_{2}$ & LIF \\
\hline BBR & Bucholtz & Broadband solar and IR & Radiometers \\
\hline SSFR & Schmidt & Spectral solar irradiance & Solar spectral flux radiometer \\
\hline PI-Neph & Martins & $\begin{array}{l}\text { Aerosol phase function and scattering } \\
\text { coefficient }\end{array}$ & PI nephelometer \\
\hline CAFS & Hall & Actinic flux & Collection, dispersion spectroscopy \\
\hline DLH & Diskin & $\mathrm{H}_{2} \mathrm{O}$ vapor & TDL spectroscopy \\
\hline LARGE & Anderson & $\begin{array}{l}\text { Aerosol number concentration, size } \\
\text { distribution }(0.0 \mathrm{I}-5 \mu \mathrm{m}) \text {, and optical properties }\end{array}$ & $\begin{array}{l}\text { CPC, optical and mobility particle sizers, } \\
\text { nephelometry, absorption photometry }\end{array}$ \\
\hline $\mathrm{CCN}$ & Nenes & $\mathrm{CCN}$ concentration & DMT CCN \\
\hline AOP & Brock & $\begin{array}{l}\text { Aerosol size distribution, aerosol absorption, } \\
\text { extinction }\end{array}$ & $\begin{array}{l}\text { UHSAS, PAS, CRD aerosol extinction } \\
\text { spectrometer }\end{array}$ \\
\hline DASH & Sorooshian & Aerosol hygroscopic growth factor & DASH-SP \\
\hline PALMS & Froyd & Single-particle chemical composition & Laser mass spectrometry \\
\hline HD-SP2 & Gao & Black carbon mass, hygroscopicity & $\begin{array}{l}\text { Humidified dual single-particle } \\
\text { photometer }\end{array}$ \\
\hline AMS & Jimenez & $\begin{array}{l}\text { Chemically speciated submicron particulate } \\
\text { mass }\end{array}$ & TOF-AMS \\
\hline DIAL HSRL & Hair & $\mathrm{O}_{3}$ and aerosol profiles & Lidar \\
\hline SPEC & Lawson & SPEC & 2D-S \\
\hline MMS & Bui & Pressure, temperature, 3D winds & Various \\
\hline Aircraft & $\begin{array}{l}\text { NASA Airborne } \\
\text { Science Program }\end{array}$ & Basic meteorological and aircraft state data & Digital cameras \\
\hline
\end{tabular}

${ }^{a}$ A description of the instruments can be found at www-air.larc.nasa.gov/cgi-bin/ArcView/dc3-seac4rs.

${ }^{\mathrm{b}}$ TD-LIF = thermal-dissociation laser-induced fluorescence. NDIR = nondispersive infrared spectrometer. PTR-MS = proton-transferreaction mass spectrometer. $\mathrm{GC}=$ gas chromatography. $\mathrm{PI}=$ polarized imaging. $\mathrm{MC} / \mathrm{IC}=$ mist chamber/ion chromatograph. $\mathrm{CPC}=$ condensation particle counter. CCN = cloud condensation nuclei. DMT = Droplet Measurement Technologies. UHSAS = ultra-high sensitivity aerosol spectrometer. PAS = photoacoustic spectrometer. CRD = cavity ring down. DASH-SP = differential aerosol sizing and hygroscopicity spectrometer probe.TOF-AMS = time-of-flight aerosol mass spectrometer. 2D-S = two-dimensional stereo.

c MPN = methyl peroxy nitrate, $\mathrm{PN}=$ peroxy nitrates, $\mathrm{AN}=$ alkyl nitrates .

${ }^{d} \mathrm{C}_{5} \mathrm{H}_{10} \mathrm{O}_{3}=$ dihydroxy isoprene epoxides, $\mathrm{C}_{5} \mathrm{H}_{8} \mathrm{O}_{3}=$ isoprene hydroxyperoxyaldehydes, $\mathrm{ETHLN}=$ ethanal nitrate, GLYC = glycolaldehyde, $\mathrm{HAC}=$ hydroxyacetone, $\mathrm{HCN}=$ hydrogen cyanide, IEPOX = isoprene epoxides, ISOPN = isoprene hydroxynitrates, ISOPOOH = isoprene hydroxyperoxides, PAA = peroxyacetic acid, $\mathrm{PROPNN}=$ propanone nitrate. 
TABLE 4. Payload for the DLR Falcon during DC3.* UV = ultraviolet. GC/FID = gas chromatography with flame ionization detection. $\mathrm{CN}=$ condensation nuclei.

\begin{tabular}{|c|c|c|c|}
\hline Instrument & PI & Species/parameter & Method \\
\hline TE49C & Schlager & $\mathrm{O}_{3}$ & UV absorption \\
\hline SRI & Schlager & NO & Chemiluminescence \\
\hline SR2 & Schlager & Total reactive nitrogen $\left(\mathrm{NO}_{y}\right)$ & $\begin{array}{l}\text { Au-reduction converter }+ \\
\text { chemiluminescence }\end{array}$ \\
\hline Aerolaser & Schlager & $\mathrm{CO}$ & VUV fluorescence \\
\hline PICARRO & Schlager & $\mathrm{CO}_{2}, \mathrm{CH}_{4}$ & CRDS \\
\hline Canisters & Rappenglueck & VOCs & GC/FID \\
\hline Cl-ITMS & Aufmhoff & $\mathrm{SO}_{2}, \mathrm{HNO}_{3}$ & CIMS \\
\hline Multichannel CPC & Minikin & Total and nonvolatile $\mathrm{CN}$ concentration & $\begin{array}{l}\text { Condensation particle counter } \\
\text { with/without thermal denuder }\end{array}$ \\
\hline OPC (Grimm) & Minikin & $\begin{array}{l}\text { Aerosol number concentration and size }(0.25-2 \\
\mu \mathrm{m})\end{array}$ & Optical scattering \\
\hline FSSPI00 & Minikin & $\begin{array}{l}\text { Cloud particle number concentration and size } \\
(2-50 \mu \mathrm{m})\end{array}$ & Optical scattering \\
\hline UHSAS & Minikin & $\begin{array}{l}\text { Aerosol particle number concentration and size } \\
(60 \mathrm{~nm}-1 \mu \mathrm{m})\end{array}$ & Optical scattering \\
\hline PCASP & Minikin & Aerosol particle number and size $(0.1-3 \mu \mathrm{m})$ & Optical scattering \\
\hline PCAP & Minikin & Soot absorption & Light attenuation through a filter \\
\hline SP-2 & Weinzierl & Black carbon mass & Single-particle photometry \\
\hline Aircraft & Zoeger & Basic meteorological and aircraft state data & Various \\
\hline
\end{tabular}

*A description of the instruments can be found at www-air.larc.nasa.gov/cgi-bin/ArcView/dc3?FALCON=I.

$\mathrm{HO}_{2}$, and the differential absorption lidar (DIAL) that obtained profiles of aerosol extinction and ozone. The Falcon aircraft obtained measurements of key trace gases and aerosols (Table 4). All three aircraft sampled several of the same species, including $\mathrm{O}_{3}, \mathrm{CO}$, $\mathrm{CO}_{2}, \mathrm{CH}_{4}$, VOCs, and NO. The NCAR GV and NASA DC-8 both sampled $\mathrm{NO}_{2}$; a range of soluble trace gases including $\mathrm{HNO}_{3}, \mathrm{H}_{2} \mathrm{O}_{2}, \mathrm{CH}_{2} \mathrm{O}$, and $\mathrm{CH}_{3} \mathrm{OOH}$; as well as biomass-burning (BB) tracers (e.g., $\mathrm{CH}_{3} \mathrm{CN}$ and $\mathrm{HCN}$ ). By flying two of the aircraft wingtip to wingtip for several minutes at different altitudes, the agreement between the instrument measurements could be evaluated. The NASA DC- 8 and DLR Falcon conducted one intercomparison, while the NASA DC-8 and NCAR GV had five intercomparisons during the campaign.

Of the 20 storms that were sampled by the three aircraft, 11 storms were sampled in a coordinated fashion by the GV and DC- 8 aircraft and the ground facilities. Measurements in 3 of these 11 storms were collected by all three aircraft in a coordinated fashion. The GV and DC-8 aircraft sampled the aged convective outflow of five of the storms that were sampled the previous day, while the DLR Falcon sampled aged convective outflow during one flight. A highlight photochemical-aging study was the 21 June 2012 case where first the DC- 8 , then the GV, sampled the convective outflow of a decaying MCS.

\section{STORM AND CHEMICAL ENVIRONMENTS} OF THE THREE REGIONS. By targeting storms in three regions of the United States, different storm types and different chemical environments were sampled. Here, we contrast the storm and chemical environments of the three regions.

The DC3-sampled thunderstorms over the high plains of northeast Colorado are predominantly shearorganized storms with moderate to high convective available potential energy (CAPE; Fig. 6). The low-level airflow is often from the southeast and upper-level flow is usually from the west. The Colorado storms have high cloud bases, because the warm and dry boundary layers in the region require higher-altitude lifting condensation levels, resulting in a smaller warm-cloud depth and a more vigorous mixed-phase region. The thunderstorms in Oklahoma and west Texas are primarily shear-organized storms, but some airmass storms (low vertical wind shear) can occur. Most storms observed in Alabama occurred in low vertical shear environments with low CAPE 


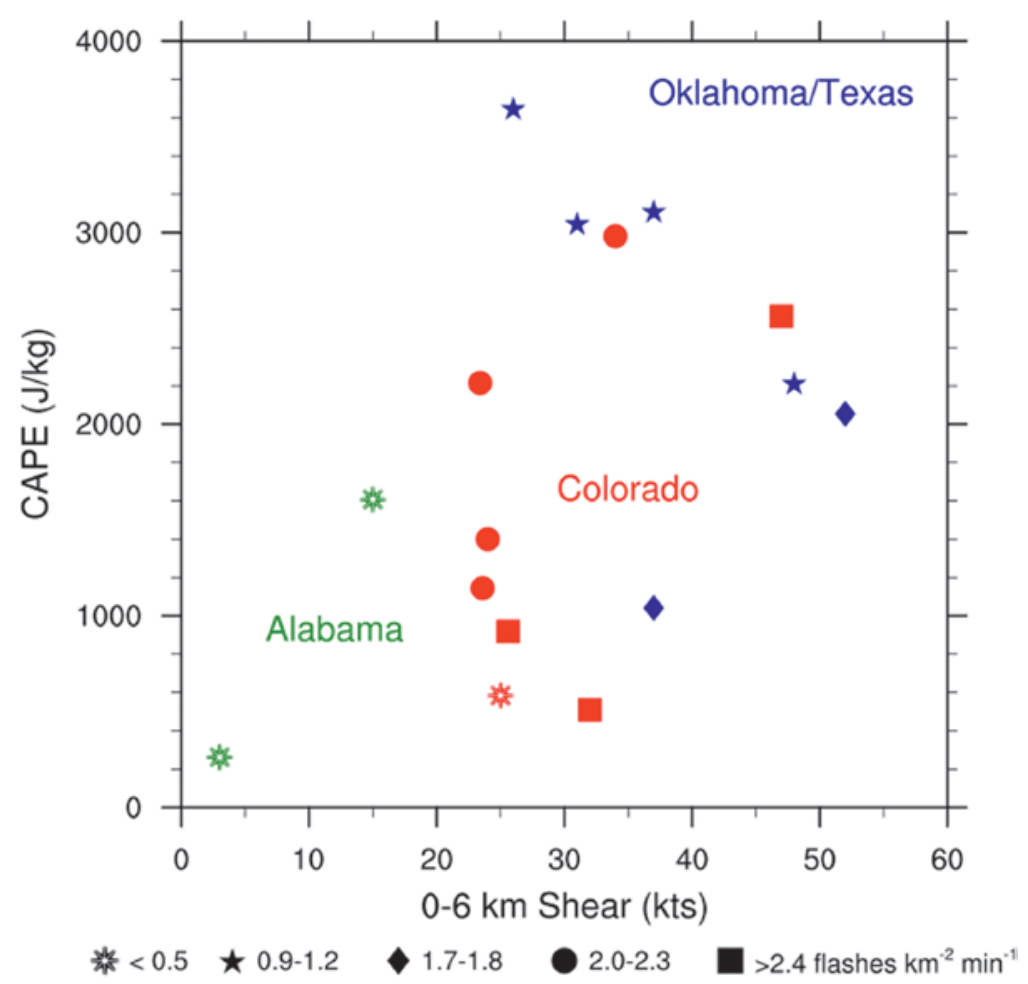

FIG. 6. The correspondence between vertical wind shear $(0-6 \mathrm{~km})$ and CAPE $\left(\mathrm{J} \mathrm{kg}^{-1}\right)$ for the DC3 storms sampled by the aircraft. Blue markers represent storms in the Oklahoma-Texas region, red markers represent storms in the northeast Colorado region, and green markers represent storms in the northern Alabama region. The data are further separated by the maximum value of the 95th percentile flash rate density (flashes $\mathrm{km}^{-2} \mathrm{~min}^{-1}$, with values given in the legend) for each case.

$\left(<2000 \mathrm{~J} \mathrm{~kg}^{-1}\right)$ although shear-organized storms, associated with cold fronts, can occur in midspring.

The lightning characteristics of the three regions also varied because of their different storm environments. We expect lightning flash rate to correlate with CAPE and vertical wind shear based on previous studies that show a positive relation between CAPE and lightning flash rate (e.g., Williams et al. 1992, 2005; Gilmore and Wicker 2002; Qie et al. 2003). Previous work has also connected flash extent and vertical wind shear (Huntrieser et al. 2008). Here, we use the lightning flash density, which allows the flash rate to be normalized by the area where flashes are occurring. We calculate the lightning flash rate density by counting the number of flashes in a $3 \times 3 \mathrm{~km}^{2}$ grid box for every 5 -min time period (the flash rates are estimated by grouping individual VHF radiation bursts associated with lightning). From the collection of all grid boxes over the LMA region, we extract the 95th percentile values. The maxima of the 95th percentile shows that there are more than 2 flashes per kilometer per minute (flashes $\mathrm{km}^{-2}$ $\mathrm{min}^{-1}$ ) in Colorado storms (Fig. 6) sampled by the aircraft except for the weak convection observed on 5 June. The lightning flash rate density is high (and higher than the other two DC3 regions) because of the high IC flash rates that commonly occur in the high plains (e.g., Boccippio et al. 2001). The storms in Oklahoma observed during DC3 by the aircraft and ground facilities had 1-2 flashes $\mathrm{km}^{-2} \mathrm{~min}^{-1}$, which is somewhat less than those found in Colorado (Fig. 6). In contrast, the two storms sampled in Alabama by the aircraft had lightning flash densities less than 0.5 flashes $\mathrm{km}^{-2} \mathrm{~min}^{-1}$. The storm flash rates in the Alabama storms were generally less than those found in the other two regions because of the different type of convection (lowshear, low-CAPE-producing smaller regions of graupel and lower supercooled water contents) in Alabama. While we conclude here that flash densities are greatest in the northeast Colorado region, storm-total flash rates in Oklahoma were similar to those in Colorado because the sizes of the sampled Oklahoma storms were often larger than those in Colorado.

The DC3 Colorado region comprises an urban corridor along with agriculture and ranching activities. Low-altitude aircraft measurements showed moderate to high anthropogenic VOCs but low biogenic VOCs except over the Rocky Mountain foothills. This relationship can be illustrated using toluene and isoprene to represent anthropogenic and biogenic VOCs, respectively (Fig. 7). To characterize the aerosols in the region, we use the dry aerosol extinction coefficient as a proxy for aerosol abundance and the organic aerosol fraction of the particulate matter smaller than $1 \mu \mathrm{m}$ (PM1). The dry aerosol extinction coefficient represents the amount of radiation (for the instrument used here, at 532-nm wavelength) that is either scattered or absorbed by particles in the accumulation and coarse modes (which constitute nearly all the mass of the particles) at low relative humidity. Its units of per megameter $\left(\mathrm{Mm}^{-1}\right.$, or $\left.10^{-6} \mathrm{~m}^{-1}\right)$ can be related to the visible distance a human eye can see. Aerosol loadings in the northeast Colorado BL (Fig. 8) range from clean to typical values of $10-30 \mathrm{Mm}^{-1}$ for rural areas (Andrews 


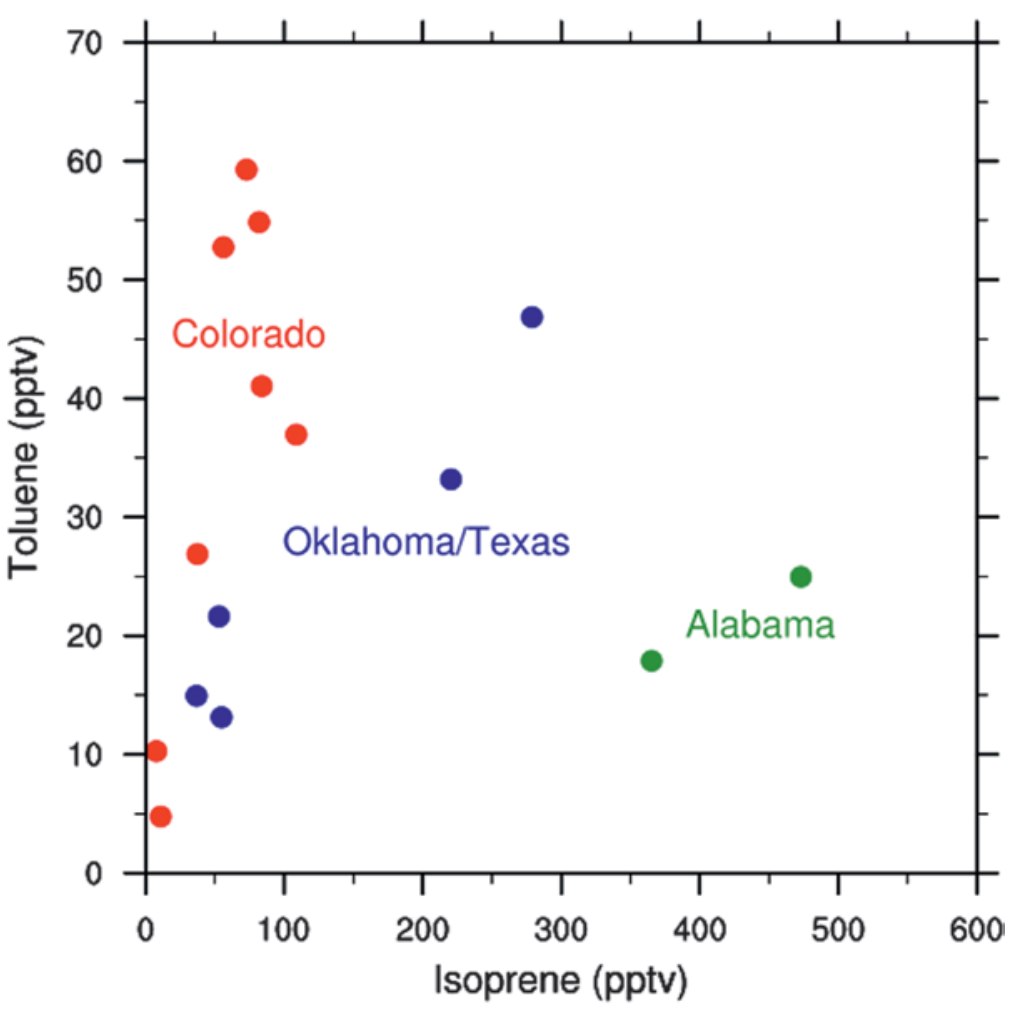

FIG. 7. The correspondence between average isoprene and toluene mixing ratios for the $0-2-\mathrm{km}$-altitude (AGL) range as measured by the DC-8 aircraft in the three sampling regions for all the aircraft storm cases except the $\mathbf{2 7}$ and 28 Jun Colorado cases, for which the GV measurements are used. The colors of the filled circles designate which region was sampled.

et al. 2011; Cai et al. 2011). The PM1 composition was mostly organic aerosol, while sulfate, nitrate, ammonium, and black carbon had smaller contributions.

Most of the Oklahoma-west Texas region is situated over the sparsely populated southern Great Plains where agriculture, pasture, and grassland dominate. However, the eastern part of the region has more scrub oak and forests, and central Oklahoma is affected by Oklahoma City and the outflow of the Dallas-Ft. Worth metropolitan area. Measurements of the boundary layer composition showed low to moderate biogenic VOCs and relatively low to moderately high anthropogenic VOCs (Fig. 7). Aerosol loadings were mostly $20-40 \mathrm{Mm}^{-1}$, which is slightly higher than typical rural levels of $10-30 \mathrm{Mm}^{-1}$ for dry aerosol extinction coefficient (Fig. 8). The contribution of $\mathrm{BL}$ organic aerosol to the PM1 composition was $45 \%-60 \%$ for all the Oklahoma-west Texas cases except for the 19 May 2012 case.

Northern Alabama-southern Tennessee is a forested area producing high levels of the biogenic VOC isoprene (Fig. 7). The area has regional anthropogenic influences and the city of Birmingham nearby produces moderate toluene levels and aerosol loadings (Fig. 8). The $\mathrm{BL}$ organic aerosol contribution to PM1 was approximately $40 \%$. Sulfate had a larger contribution in this region compared to Colorado and Oklahoma-west Texas.

SELECTED CASES. The Mayearly June 2012 synoptic meteorology over the United States was characterized by troughs and ridges propagating from west to east, which is a typical pattern for the midlatitudes. The southern United States dried out and progressed into drought conditions during June owing to a stationary high pressure area over the region. Wildfires were abundant over the Rocky Mountain region (Johnson et al. 2014; Lang et al. 2014). In May, these wildfires were mostly in Arizona and New Mexico (Whitewater-Baldy fire). In June, most of the wildfires were in Colorado (notably the Hewlett Gulch and High Park fires near Ft. Collins), Utah, and Wyoming.

Table 5 lists all the DC 3 cases with information on the weather and which aircraft facilities were operational. Five DC3 cases stand out as exceptional events to focus on. A storm case from each sampling region was selected to examine thunderstorm characteristics and tracegas and aerosol redistribution. Two of these storms included a second-day sampling of their convective outflow to address goal 2. A second case from Colorado was chosen because of its isolated nature and its uniqueness in that the storm ingested a biomass-burning plume at about $7-\mathrm{km}$ altitude. To understand the photochemical aging of fresh convective outflow, a decaying mesoscale convective system case was selected. These five cases are described briefly here. In addition to the weather scenario, lightning data and vertical profiles of trace gases are presented. The lightning data time series discussed for each case are the total flash rates for the storm in the DC3 target region, which frequently encompassed multiple cells and evolved with time to remain with those cells. Also reported are the average and standard deviation of the flash extent estimated from the square root of the area of a polygon drawn around each flash (Bruning and MacGorman 2013). In other, more detailed studies 


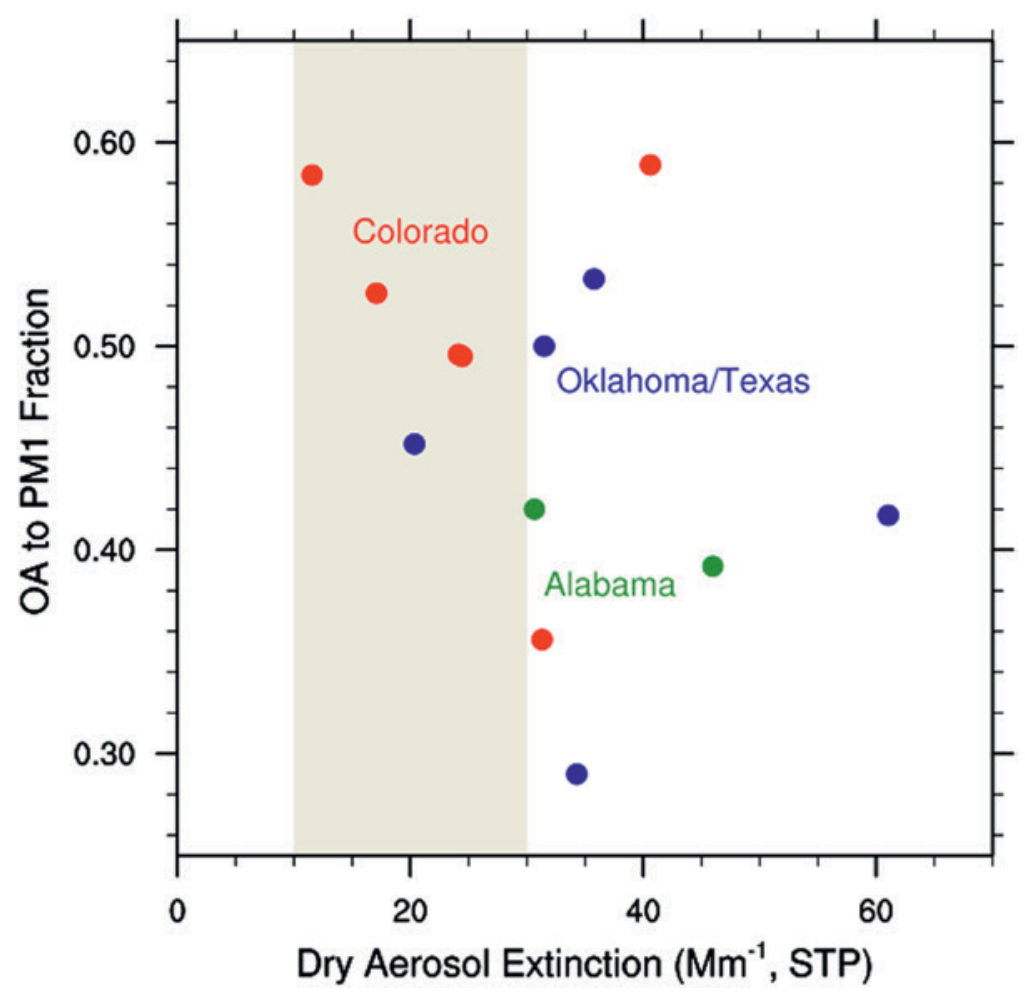

FIG. 8. The correspondence between average dry aerosol extinction $\left(\mathrm{Mm}^{-1}\right)$ and mass concentration ratio of organic aerosol (OA) to PMI (=sulfate + organic + nitrate + ammonium + chlorine + black carbon) aerosols for the $0-2-\mathrm{km}$-altitude (AGL) range as measured by the DC-8 aircraft in the three sampling regions. The colors of the filled circles designate which region was sampled, and the shaded region represents typical rural values of dry aerosol extinction. production of $\mathrm{NO}_{x}$ by lightning, and photochemistry will be presented in future publications on DC3.

Weak convection case. The synoptic weather on 21 May 2012 began with a weak cold front extending southward from Michigan through the Mississippi River valley and then westward as a stationary front through northern Texas. Convection occurred in the early morning in northern Alabama and Mississippi. By early afternoon, extensive convection formed in weak shear and low instability along a prefrontal trough in Tennessee, northern Alabama, and Mississippi as the cold front moved southward to the Gulf Coast states. An isolated thunderstorm developed in southern Tennessee, within the northern dual-Doppler lobes (Fig. 9), and was targeted for sampling by the DC- 8 and GV aircraft as well as the ground-based LMA, radar, and sounding units. This prefrontal convection had updrafts of $10-20 \mathrm{~m} \mathrm{~s}^{-1}$, creating a small graupel region (Bain 2013). Flash rates in the northern Alabama region peaked at 8 flashes per minute (Fig. 10a). The mean

(e.g., Bain 2013), these lightning data are found to be correlated with storm microphysics parameters (e.g., graupel volume) and with the estimated production of $\mathrm{NO}_{x}$ from lightning to learn what storm characteristics are important to lightning and how the horizontal and vertical placement of lightning affects lightning $\mathrm{NO}_{x}$. The vertical profiles are data combined from the two or three aircraft sampling the storm and averaged into $0.5-\mathrm{km}$ bins. $\mathrm{CO}$, toluene, isoprene, and $\mathrm{O}_{3}$ are shown to illustrate convective transport of gases in the thunderstorm environment. As very soluble species, $\mathrm{HNO}_{3}$ and $\mathrm{H}_{2} \mathrm{O}_{2}$ vertical profiles should indicate scavenging by the storm. $\mathrm{CH}_{2} \mathrm{O}$ is shown because it is an important source of $\mathrm{HO}_{x}$ radicals, yet has complicated behavior in storms because it is moderately soluble and photochemically reactive. $\mathrm{NO}_{x}$ vertical profiles indicate the importance of lightning as a $\mathrm{NO}_{x}$ source by comparing mixing ratios in the UT to those in the $\mathrm{BL}$. The $10 \%$ and $90 \%$ mixing ratios for $\mathrm{CO}, \mathrm{CH}_{2} \mathrm{O}$, and $\mathrm{NO}_{x}$ in the UT are also shown to contrast convective outflow (90\% values) with UT background (10\% values). Detailed analysis of convective transport, scavenging, flash extent for this thunderstorm was $8-12 \mathrm{~km}$ and showed a tendency to have larger flashes when the flash rate was low and vice versa (Fig. 10a). The anticorrelation of flash extent and flash rate indicates that when the flash rate is high the charge centers are more compact and are near strong updrafts (Bruning and MacGorman 2013). This isolated thunderstorm occurred in a region of high BL VOCs (isoprene reached a few parts per billion by volume and $\mathrm{CH}_{2} \mathrm{O}$ reached approximately $2.5 \mathrm{ppbv})$ and low $\mathrm{BL} \mathrm{NO}_{x}(\sim 50 \mathrm{pptv})$. By comparing the outflow region in the UT (defined at altitudes between $7 \mathrm{~km}$ and the tropopause) to the BL (altitudes below $2.5 \mathrm{~km}$ ), we find signatures of convective transport with $\mathrm{CO}$ enhanced by about 20 ppbv (Fig. 10b), scavenging of soluble gases, as indicated by suppressed $\mathrm{H}_{2} \mathrm{O}_{2}$ and $\mathrm{CH}_{2} \mathrm{O}$ mixing ratios in the UT region compared to the BL (Figs. 10c,d) and lightning production of $\mathrm{NO}_{x}$ with $\mathrm{UT} \mathrm{NO}_{x}$ reaching over 900 pptv (Fig. 10d). However, there was no pronounced enhancement of toluene and isoprene in the UT region compared to the BL likely because of the short chemical lifetimes of these VOCs. 


\begin{tabular}{|c|c|c|c|c|}
\hline Date & Location & Aircraft & Storm targeted & Features \\
\hline 18 May & $\mathrm{CO}$ & DC-8, GV & $\begin{array}{l}\text { High plains convection in vicinity of } \\
\text { a front }\end{array}$ & $\begin{array}{l}\text { Anthropogenic VOC sampling } \\
\text { in } B L\end{array}$ \\
\hline 19 May & OK & DC-8, GV & $\begin{array}{l}\text { Line of supercell convection in } \\
\text { western Oklahoma }\end{array}$ & - \\
\hline 21 May & $\mathbf{A L}$ & DC-8, GV & Weak, prefrontal convection & - \\
\hline 25 May & OK & DC-8, GV & $\begin{array}{l}\text { Supercell convection at Oklahoma- } \\
\text { Texas Panhandle border }\end{array}$ & - \\
\hline 26 May & IL & DC-8, GV & Downwind flight & Biogenic VOC sampling in $\mathrm{BL}$ \\
\hline 29 May & OK & DC-8, GV, Falcon & $\begin{array}{l}\text { Supercell/MCS in northern } \\
\text { Oklahoma }\end{array}$ & - \\
\hline 29 May & TX & Falcon & Biomass-burning plume & - \\
\hline 30 May & TN-NC & DC-8, GV & Downwind flight & Intercomparison flight legs \\
\hline 30 May & $T X$ & Falcon & Supercells & - \\
\hline I Jun & $\mathrm{CO}, \mathrm{TX}$ & DC-8, GV & Multicells in TX Panhandle & $\begin{array}{l}\text { Anthropogenic VOC sampling } \\
\text { in } \mathrm{BL}\end{array}$ \\
\hline 2 Jun & $\mathrm{CO}$ & DC-8 & Isolated convection and squall line & - \\
\hline 5 Jun & $\mathrm{CO}$ & DC-8, GV & Weak isolated mountain storm & $\begin{array}{l}\text { Aged convective outflow in } \\
\text { region }\end{array}$ \\
\hline 5 Jun & $\mathrm{TX}$ & Falcon & $\begin{array}{l}\text { Convection associated with a } \\
\text { mesoscale convective vortex }\end{array}$ & $\begin{array}{l}\text { Aged convective outflow in } \\
\text { CO-KS }\end{array}$ \\
\hline 6 Jun & OK & None & Squall line & - \\
\hline 6 Jun & $\mathrm{CO}$ & DC-8, GV, Falcon & $\begin{array}{l}\text { Convection associated with } \\
\text { Denver cyclone } \\
\end{array}$ & - \\
\hline 7 Jun & IL-MO & DC-8, GV & Downwind flight & Biogenic VOC sampling in BL \\
\hline 7 Jun & $\mathrm{CO}$ & None & Isolated supercells & - \\
\hline 8 Jun & KS-MO & Falcon & $\begin{array}{l}\text { Aged anvil outflow of storms previously } \\
\text { in Colorado }\end{array}$ & - \\
\hline II Jun & $\mathrm{AL}$ & DC-8, GV & Weak isolated storm & - \\
\hline II Jun & MO-AR & DC-8, GV, Falcon & MCS & DC-8 and Falcon intercomparison \\
\hline 12 Jun & CO-KS & Falcon & Multicell convection & - \\
\hline 14 Jun & KS & Falcon & Aged outflow & - \\
\hline 15 Jun & $\mathrm{CO}$ & DC-8, GV & Multicell cluster over Denver & BB plume sampling \\
\hline 16 Jun & $\mathrm{TX}-\mathrm{OK}$ & DC-8, GV & Multicell convection and MCS & - \\
\hline 17 Jun & LA,TX & DC-8, GV & Downwind flight & Intercomparison profile \\
\hline 21 Jun & MO & DC-8, GV & Dissipating MCS & Photochemical aging \\
\hline 22 Jun & co & DC-8, GV & Isolated supercells & $\begin{array}{l}\text { BB plume ingested into } \\
\text { storm }\end{array}$ \\
\hline 23 Jun & AR-TN & GV & Downwind flight & - \\
\hline 25 Jun & Gulf of Mexico & GV & Aged outflow & - \\
\hline 27 Jun & $\mathrm{CO}$ & GV & $\begin{array}{l}\text { Weakly organized storms associated } \\
\text { with a cold front }\end{array}$ & - \\
\hline 28 Jun & $\mathrm{CO}$ & GV & Disorganized, widespread storms & - \\
\hline 30 Jun & $\mathrm{KS}, \mathrm{TX}$ & GV & No storms; partly cloudy skies & $\begin{array}{l}\text { Anthropogenic VOC sampling } \\
\text { in } \mathrm{BL}\end{array}$ \\
\hline
\end{tabular}




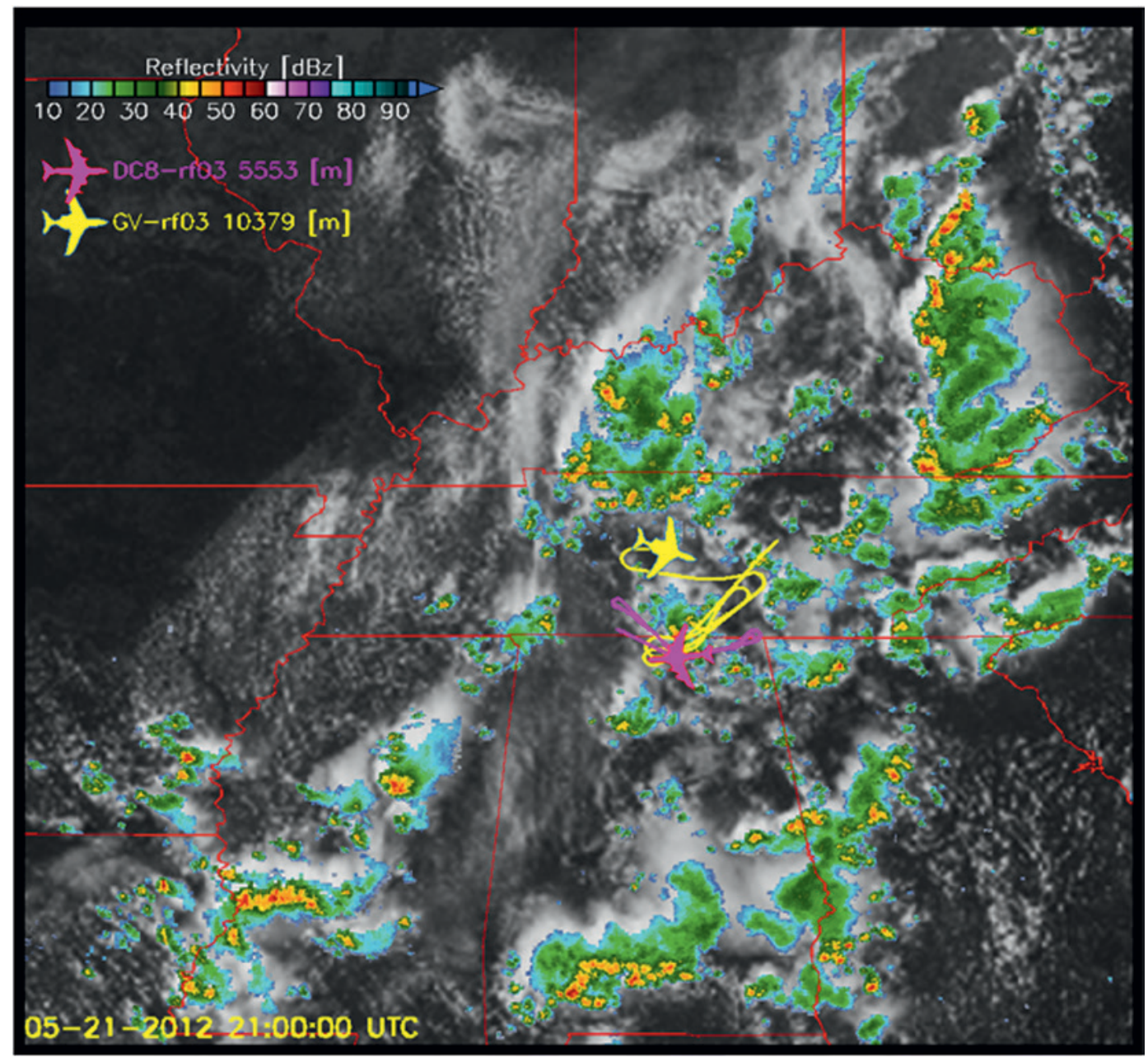

FIG. 9. Composite radar and satellite mosaic at 2100 UTC 21 May 2012 for the weak convective case. The storms were moving toward the south-southeast. The pink and yellow lines are the DC-8 and GV aircraft flight legs, respectively, for a I-h period ending at 2100 UTC where the airplane symbols are located.

Severe convection case. The 29 May 2012 Oklahoma case was composed of a line of isolated supercell storms from northern through central Oklahoma that produced strong winds, large hail, and an enhanced Fujita scale 1 (EF1) tornado. The morning weather showed a cold front stretching from the Ohio Valley southward and arcing back into northern Oklahoma and southern Kansas. Ahead of the front and dryline, which was positioned in extreme western Texas and eastern New Mexico in the morning, the atmosphere was very unstable. By 2100 UTC, storms had initiated in northwest Oklahoma. These storms subsequently developed into a line of initially isolated supercells (Fig. 11). The GV sampled the UT convective outflow, with the DC-8 sampling the inflow followed by UT outflow sampling. The DLR Falcon also sampled the convective outflow. The mobile radars and sounding units, as well as the LMA, all gathered data on this severe convection. Stormwide flash rates increased significantly from less than 100 flashes per minute at 0000 UTC 30 May to nearly 500 flashes per minute at 0130 UTC (Fig. 12a) as the storm became more organized and a left-moving supercell merged with the storm of interest. The estimated mean flash extent was $6-9 \mathrm{~km}$. The storm occurred in a region of variable VOC mixing ratios, with concentrations higher over the eastern part of the sampling region than over the southern part of the sampling region. $\mathrm{CO}$ mixing ratios showed enhancements in the convective outflow region ( $90 \%$ values in Fig. $12 \mathrm{~b}$ ) with mixing ratios near $50 \mathrm{ppbv}$ over the UT background (10\% values). UT enhancements were also found for toluene, isoprene, and $\mathrm{CH}_{2} \mathrm{O}$ compared to the UT background. The magnitude of enhanced $\mathrm{CH}_{2} \mathrm{O}$, $\mathrm{H}_{2} \mathrm{O}_{2}$, and $\mathrm{HNO}_{3}$ in the convective outflow compared to their $\mathrm{BL}$ mixing ratios shows that moderate 


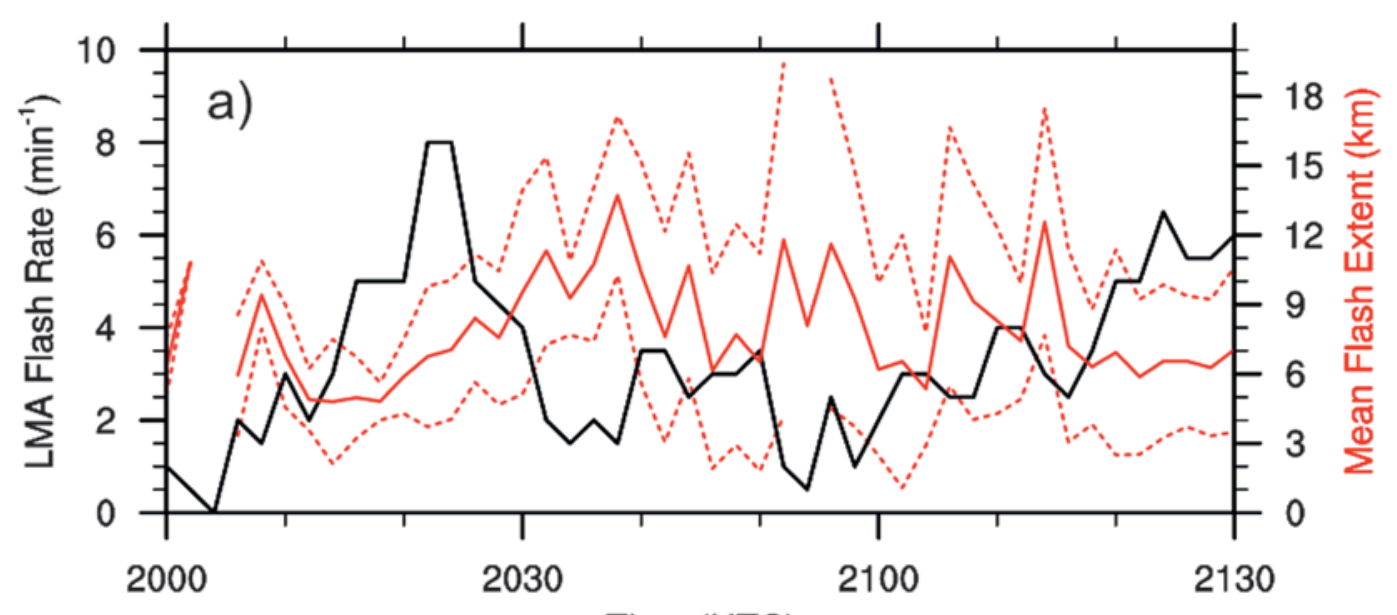

Time (UTC)
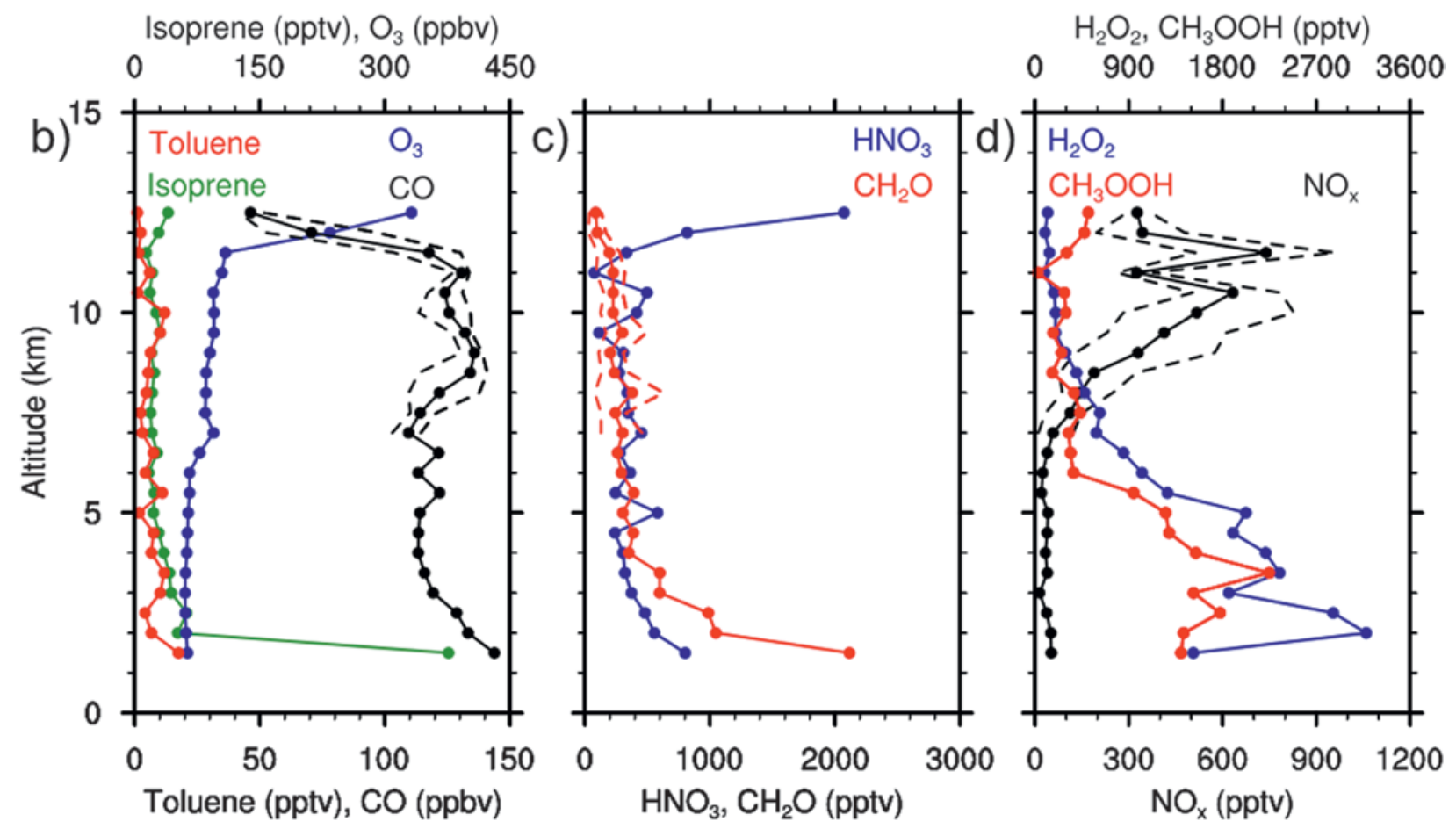

FIG. 10. (a) LMA lightning flash rate $\left(\mathrm{min}^{-1}\right)$ and mean and standard deviation flash extent (km) for the storm region. (b)-(d) Average vertical profiles in the Tennessee-Alabama region for (b) passive trace gases, (c) soluble

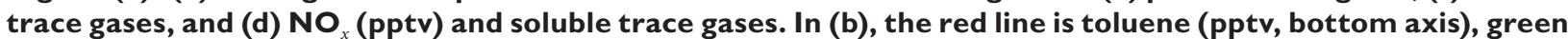
line is isoprene (pptv, top axis), blue line is ozone (ppbv, top axis), and black line is CO (ppbv, bottom axis). In (c), the blue line is $\mathrm{HNO}_{3}$ (pptv), and red line is $\mathrm{CH}_{2} \mathrm{O}$ (pptv). In (d), the black line is NO (pptv, bottom axis), blue line is $\mathrm{H}_{2} \mathrm{O}_{2}$ (pptv, top axis), and red line is $\mathrm{CH}_{3} \mathrm{OOH}$ (pptv, top axis). The dashed lines in (b)-(d) are the $10 \%$ and $90 \% \mathrm{UT}$ mixing ratios for (b) $\mathrm{CO}$, (c) $\mathrm{CH}_{2} \mathrm{O}$, and (d) $\mathrm{NO}_{x}$. Measurements of a biomass-burning plume, sampled by the GV, have been omitted.

amounts of $\mathrm{CH}_{2} \mathrm{O}$ were scavenged and most of the $\mathrm{H}_{2} \mathrm{O}_{2}$ and $\mathrm{HNO}_{3}$ were scavenged (Figs. 12c,d). $\mathrm{NO}_{x}$ was around $0.2 \mathrm{ppbv}$ in the boundary layer and more than 1000 pptv in the UT region, exhibiting substantial lightning-produced $\mathrm{NO}_{x}$ in the convective outflow (Fig. 12d). On 30 May, the GV and DC-8 aircraft flew to the southern Appalachian region to sample the aged convective outflow from the 29 May storm. The convective outflow was sampled at 10-12-km altitude with $\mathrm{CO}$ between 110 and 130 ppbv, $\mathrm{O}_{3}$ between 90 and $110 \mathrm{ppbv}$, and $\mathrm{NO}_{x}$ still elevated at $1-2 \mathrm{ppbv}$.

Strong convection case. The 6 June 2012 Colorado storm was associated with the "Denver cyclone," where low-level flow is southeasterly on the plains east of Denver and is northwesterly to the west of Denver. The 


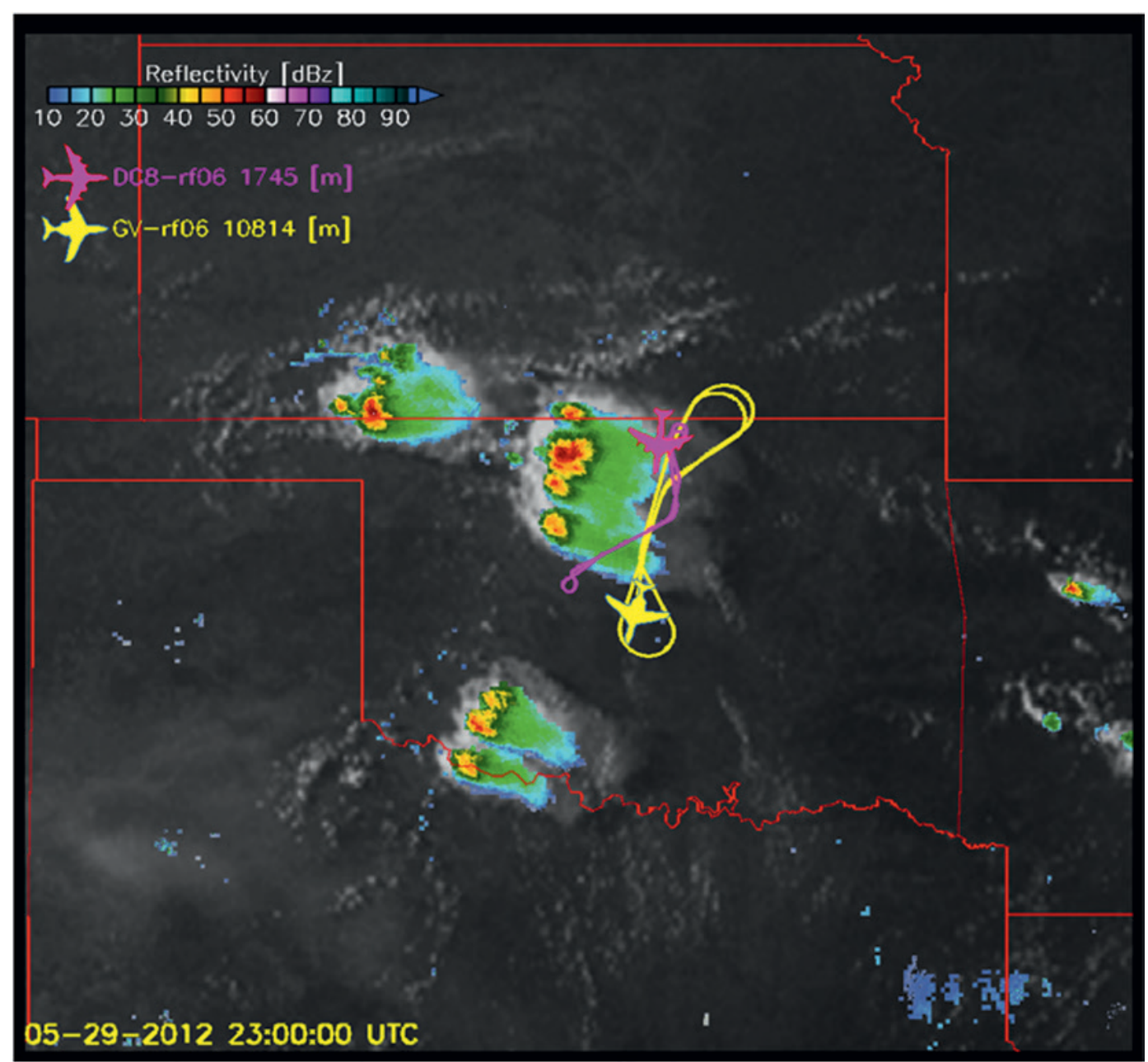

FIG. II. Composite radar and satellite mosaic at 2300 UTC 29 May 2012 for the severe convection case. The storm was moving to the east. The pink and yellow lines are the DC-8 and GV aircraft flight legs, respectively, for a I-h period ending at 2300 UTC where the airplane symbols are located. The Falcon location at the time of the radar plot was at Lubbock, TX. The Falcon sampled the storm I-I.5 h after the satellite photo..

southeasterly flow transports moisture into the area and the cyclone provides low-level convergence, which gives a focus for convective initiation. Isolated convection formed on the apex of the Denver cyclone at about 2030 UTC. As the afternoon proceeded, several convective cells formed in the DC3 network (Fig. 13). The CSUCHILL and CSU-Pawnee radars sampled three different storms, while the DC- 8 and GV sampled the inflow and outflow of two of these storm cells. The DLR Falcon also sampled convective outflow from more intense storms along the same convective line, but farther north in southeastern Wyoming. The Falcon measurements showed that in the fresh anvil outflow region, $\mathrm{O}_{3}$ mixing ratios were highly variable (70-120 ppbv), indicating a pronounced mixture of $\mathrm{O}_{3}$-poor air transported upward from the lower midtroposphere and at the same time downward mixing of $\mathrm{O}_{3}$-rich air from the UT and lower stratosphere (LS). After 0000 UTC 7 June, the north-south-oriented line of storms intensified. Severe storms were present in the northeast Denver area as late as 0400-0500 UTC. The later storms were more intense than the sampled storms, potentially contributing substantial lightning-generated $\mathrm{NO}_{x}$ flowing out of the Colorado domain. During the time when the aircraft sampled the storms, flash rates reached 400 flashes per minute and mean flash extents were around $6 \mathrm{~km}$ (Fig. 14a). Like the 21 May Alabama storm, the flash extent showed some anticorrelation with flash rate. VOC and $\mathrm{CO}$ vertical profiles show moderate enhancement in convective outflow compared to UT background air. Soluble trace gases were low in the convective outflow, indicating scavenging of these species. On 7 June, the GV and DC-8 aircraft flew to the Missouri region to sample the aged convective outflow from the 6 June 

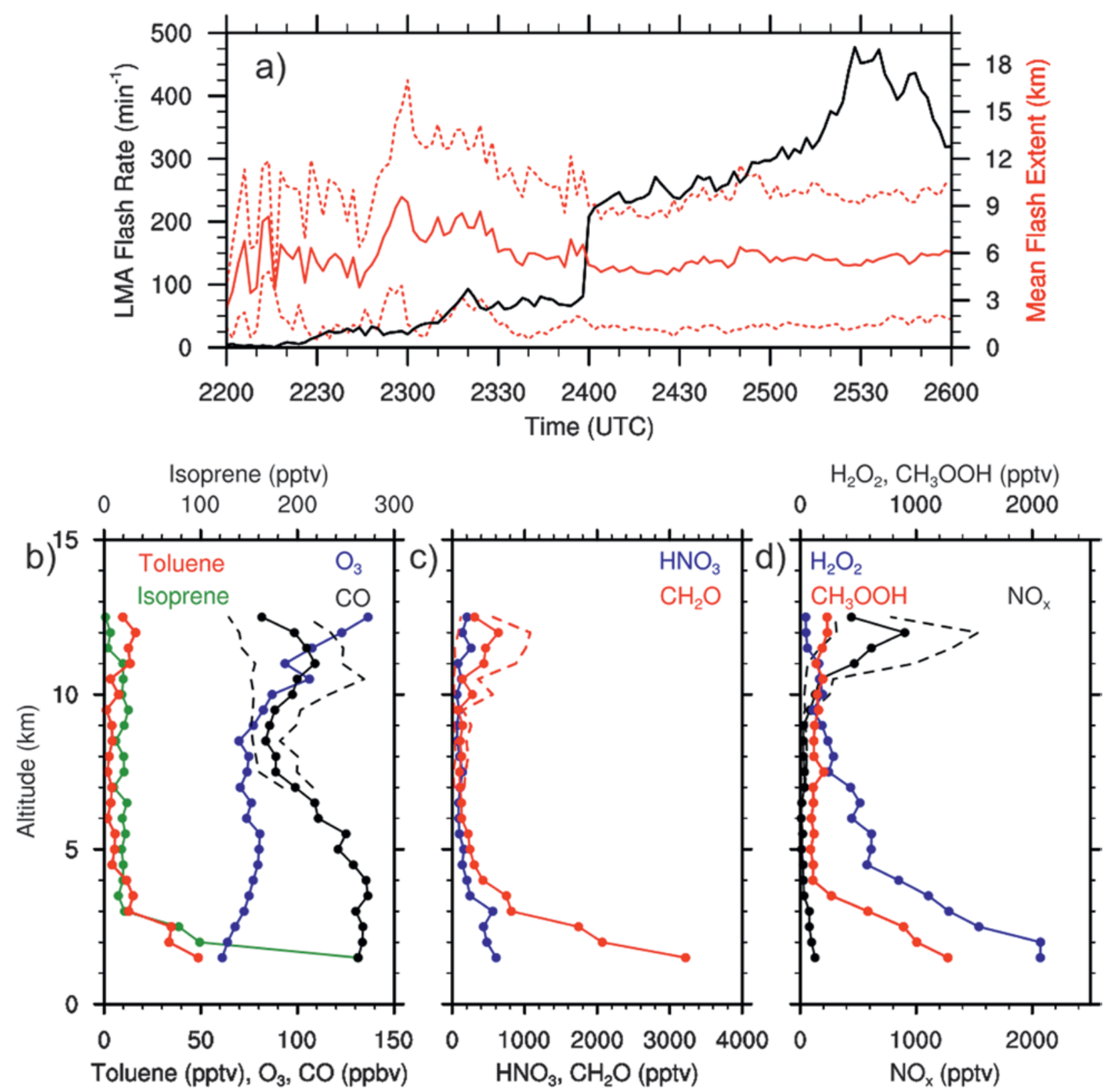

FIG. 12. As in Fig. 10, but for the 29 May 2012 Oklahoma region, the DLR Falcon measurements are included, and $\mathrm{O}_{3}$ is plotted using the bottom axis of (b).

storm. The second-day convective outflow, sampled between 10 - and $13-\mathrm{km}$ altitude, measured moderate $\mathrm{CO}$ mixing ratios (95-100 ppbv) with $\mathrm{NO}_{x}$ mixing ratios peaking over $1 \mathrm{ppbv}$ and corresponding $\mathrm{O}_{3}$ peaks of over 100 ppbv.

Smoke ingestion case. The 22 June 2012 Colorado thunderstorms sampled by the GV and DC-8 aircraft and ground facilities consisted of three isolated, severe storms. Although the 1200 UTC Denver temperature sounding showed a strong cap at about $1 \mathrm{~km}$ above ground level $(750 \mathrm{hPa})$, south-southeasterly flow in eastern Colorado and western Kansas and Nebraska and high CAPE suggested the potential for strong severe convection in northeast Colorado. In addition, the High Park fire west of Ft. Collins had been burning since 9 June 2012. Before conducting storm inflow and outflow observations, the DC-8 aircraft sampled the smoke plume from this fire near its source west of Ft. Collins. At about 2100 UTC, an isolated cell formed northwest of Akron, Colorado, located about $150 \mathrm{~km}$ northeast of Denver. As this first storm moved eastward and dissipated, a second storm began at 2230 UTC along the Cheyenne Ridge. 


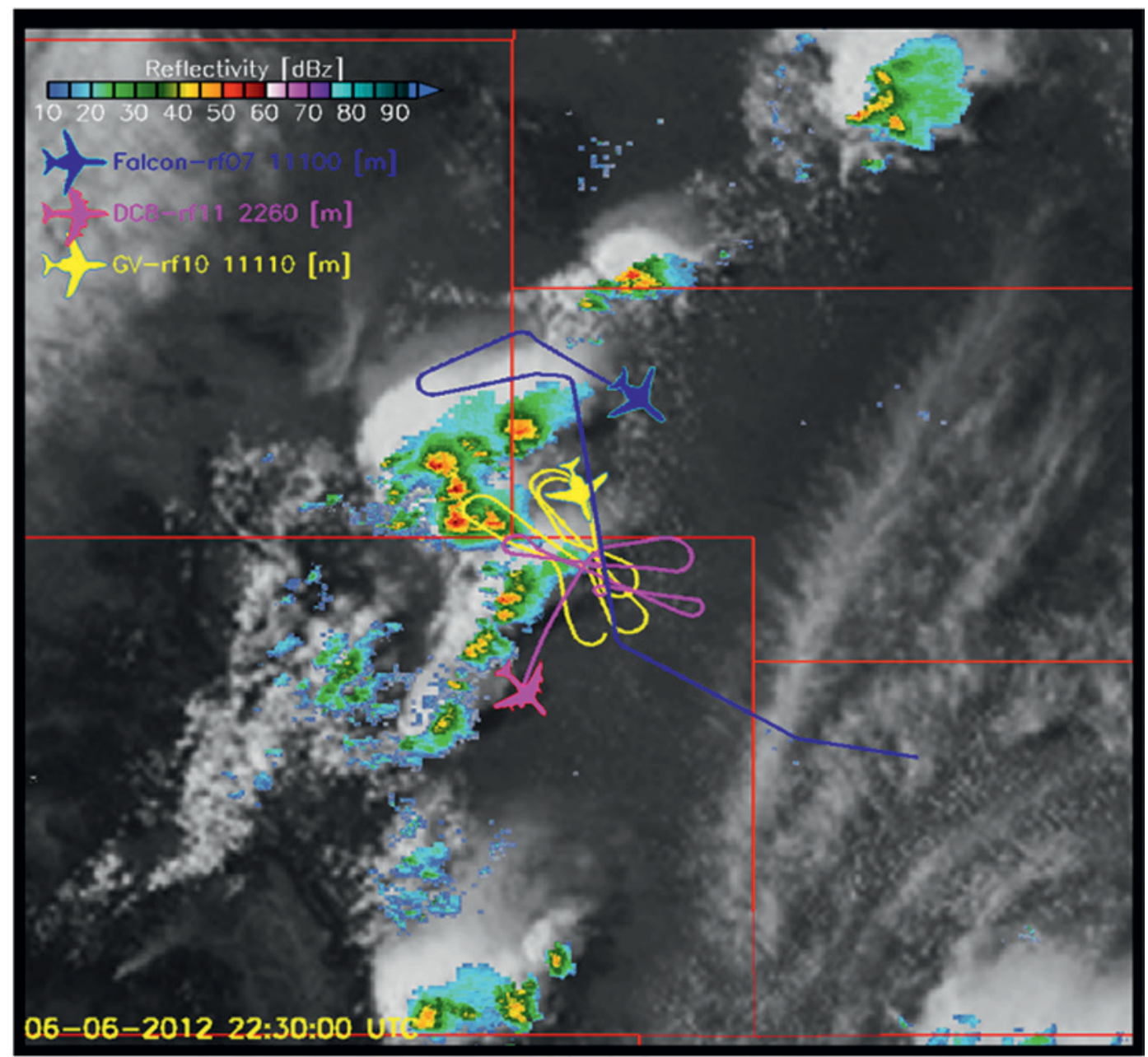

FIG. 13. Composite radar and satellite mosaic at 2230 UTC 6 Jun 2012 in the northeast Colorado-southeast Wyoming region for the strong convective case. The storms were moving to the east. The pink, yellow, and blue lines are the DC-8, GV, and Falcon aircraft flight legs, respectively, for a I-h period ending at 2230 UTC where the airplane symbols are located.

Then, a third storm formed near Ft. Morgan, Colorado, at 2330 UTC. The two DC3 aircraft sampled the inflow and outflow in all three of these storms. The lightning data obtained from the two later storms showed lightning flash rates of up to 150 flashes per minute and flash extents generally of $7-15 \mathrm{~km}$ but up to $40 \mathrm{~km}$ (within the storm anvil; Fig. 16a). The flash extent again exhibited an anticorrelation with flash rate, especially for the first $2-3 \mathrm{~h}$ of these storms. During the same time period, the High Park fire began to burn new forest, producing a copious amount of smoke flowing northeastward. By 0000 UTC 23 June, the northern (in southwest Nebraska) thunderstorm was ingesting the High Park fire smoke plume (Fig. 15). The two aircraft observed biomassburning signatures (e.g., high levels of black carbon, $\mathrm{HCN}, \mathrm{CH}_{3} \mathrm{CN}, \mathrm{CO}$, and other VOCs) in the anvil of the storm, and the DC-8 aircraft descended to sample the smoke plume just ahead of the thunderstorm at about 7-km altitude. The BL composition (Figs. 16b-d) that did not include targeted smoke plumes had approximately $\sim 120$ ppbv $\mathrm{CO}, 1-2.5$ ppbv $\mathrm{CH}_{2} \mathrm{O}$, and approximately $0.2 \mathrm{ppbv}$ of $\mathrm{NO}_{x}$. In the convective outflow, the aircraft sampled 100-120 ppbv $\mathrm{CO}$, up to 1.5 ppbv $\mathrm{CH}_{2} \mathrm{O}$, and up to $4 \mathrm{ppbv} \mathrm{NO}_{x}$. In contrast, the smoke plume at $7-\mathrm{km}$ altitude had over $1200 \mathrm{ppbv} \mathrm{CO}$, up to $35 \mathrm{ppbv} \mathrm{CH}_{2} \mathrm{O}$, and over $10 \mathrm{ppbv} \mathrm{NO}_{x}$. The unique biomass-burning trace gases and particles can be used to understand entrainment of midtropospheric air into deep convection as well as the impact of both convection and biomass burning on UT chemistry.

Dissipating MCS case. To address the second DC3 goal of photochemical aging in convective outflow 

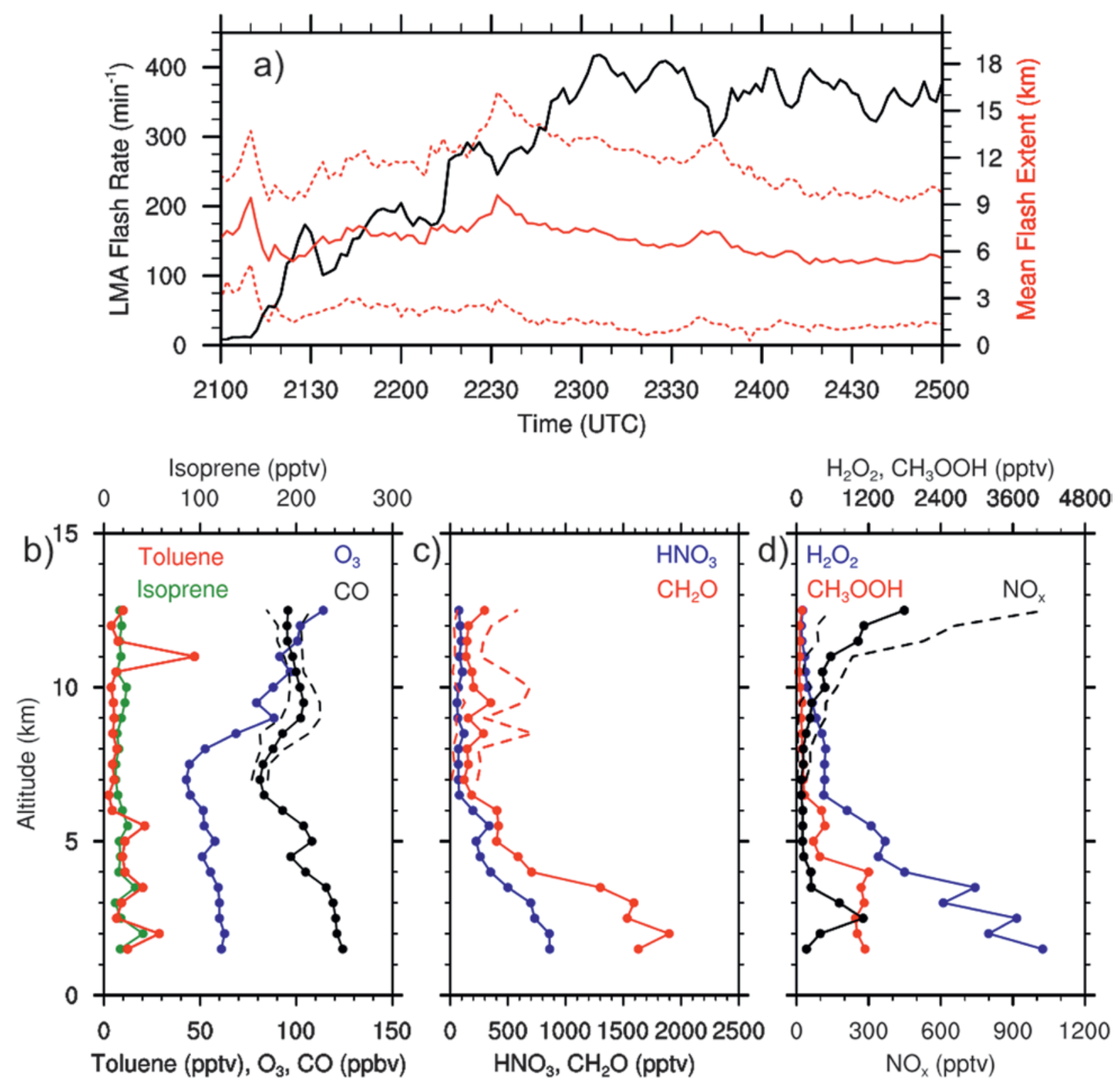

FIG. 14. As in Fig. 10, but for 6 Jun 2012 Colorado region, the DLR Falcon measurements are included, and $\mathrm{O}_{3}$ is plotted using the bottom axis in (b).

plumes, the convective outflow air mass of the 21 June 2012 decaying MCS was characterized by the GV and DC-8 aircraft. The MCS, which developed over Nebraska during the night, was located over Missouri by early morning when it began to dissipate (Fig. 17). The DC-8 aircraft flew to the convective outflow region and began traversing the storm outflow at $11 \mathrm{~km}$ in a southwest-northeast orientation. Using guidance from the aircraft winds, the plane progressively moved these flight legs eastward to remain approximately in the same air mass. The GV aircraft joined the DC- 8 at midday repeating the last half flight leg of the DC- 8 before the DC- 8 returned to the operations base. The GV continued the southwestnortheast flight legs during the afternoon progressively moving them eastward. While some convection remained active in northern Oklahoma, the MCS did dissipate during the day. Initially, the trace gas and aerosol measurements on the DC- 8 were typical for fresh convective outflow with low concentrations of soluble gases and particle number and high concentrations of CO and VOCs. By mid- to late morning, the photochemistry began to produce very high number concentrations of particles. Overall increases of late afternoon $\mathrm{O}_{3}$ mixing ratios from early morning were 15-20 ppbv (Fig. 18). The spikes in $\mathrm{O}_{3}$ seen in 


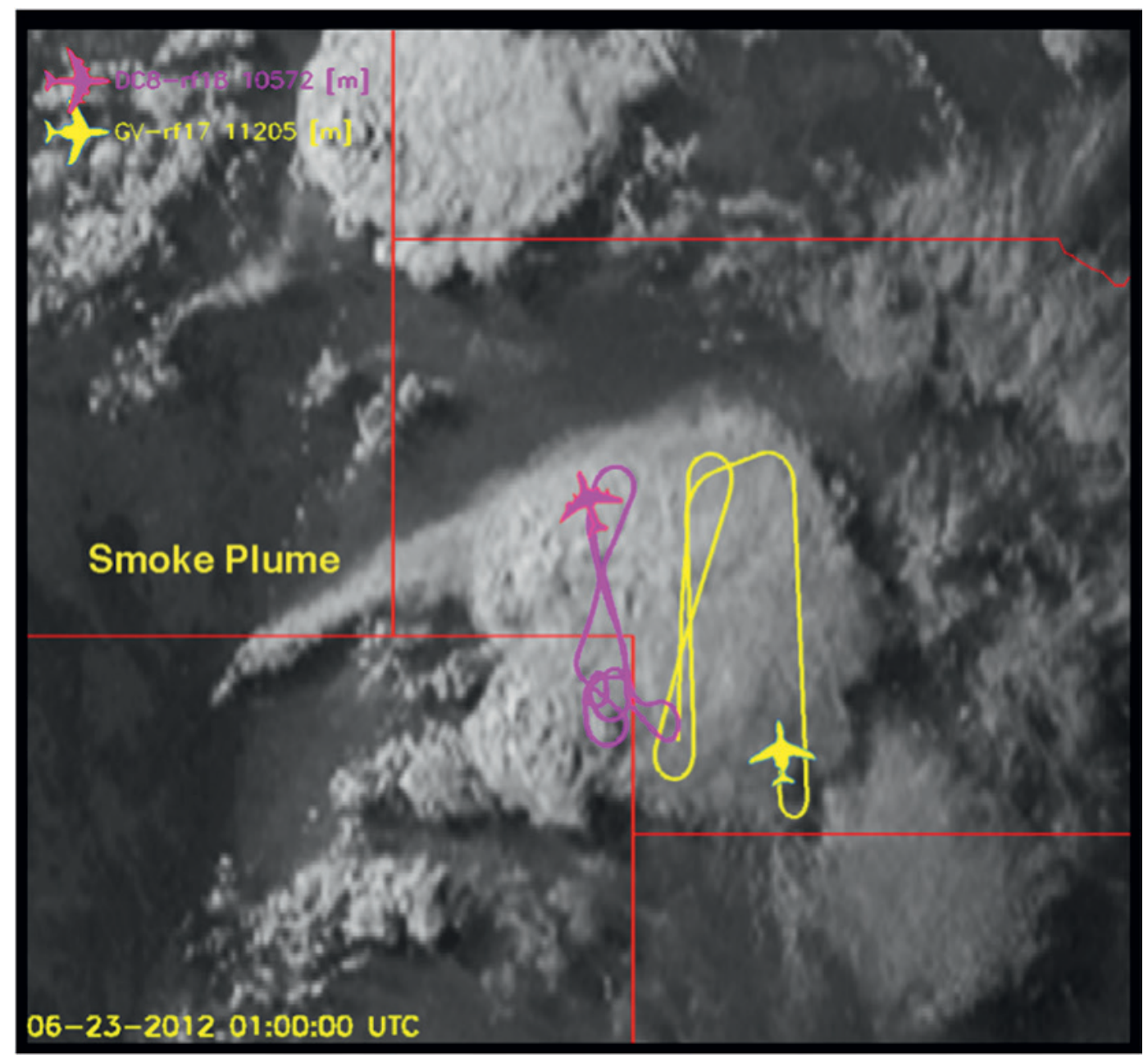

FIG. 15. Visible satellite imagery at 0100 UTC 23 Jun 2012 in the northeast Colorado-southeast Wyoming region for the smoke ingestion case. The storms were moving to the east. The pink and yellow lines are the DC-8 and GV aircraft flight legs, respectively, for the 2245-02I5 UTC period (the airplane symbols are located at 0215 UTC).

Fig. 18 are correlated with dips in $\mathrm{CO}$, indicating that these spikes are stratospheric air. Lagrangian analysis of this case should provide quantitative insight on the contributions of $\mathrm{NO}_{x}$ and $\mathrm{HO}_{x}$ to ozone as well as the conditions conducive for the new particle formation.

Interactions between storms, biomass burning, and stratospheric air. In addition to the five selected cases from the GV and DC-8 measurements, five of the DLR Falcon missions stand out as exceptional storms to analyze. The 6 June 2012 case was a coordinated flight that is described above. On 30 May 2012, the DLR Falcon investigated a supercell storm over the Texas-Oklahoma border interacting with a lofted biomass-burning plume from the Whitewater-Baldy fire in New Mexico and with $\mathrm{O}_{3}$-rich air from the upper troposphere-lower stratosphere (UTLS) region ( $150 \mathrm{ppbv})$ into the anvil outflow region down to $9 \mathrm{~km}$. NO mixing ratios in the fresh anvil outflow were on average in the range of $2-3 \mathrm{ppbv}$ (peak: 8.6 ppbv). The 8 June 2012 case was selected as the only DLR Falcon case with aged convective outflow (12-24 h), indicating a strong exchange of tropospheric and stratospheric air masses in the UTLS region over Kansas the day after active convection over Colorado. At $12-\mathrm{km}$ altitude, lightning-produced $\mathrm{NO}(0.5-1 \mathrm{ppbv})$ was injected into the lower stratosphere $\left(\mathrm{O}_{3}\right.$ mixing ratios around $250 \mathrm{ppbv}$ ) and a stratospheric intrusion mixed down to $7 \mathrm{~km}$ within the aged anvil outflow $\left(\mathrm{O}_{3}\right.$ mixing ratios around 170 ppbv). On 11 June 2012, an MCS over Missouri and Arkansas was probed by all three aircraft. A biomass-burning plume from the Little Bear fire (New Mexico), with $\mathrm{CO}$ mixing ratios up to $700 \mathrm{ppbv}$ at $7-\mathrm{km}$ altitude, was measured by the DLR Falcon as far as $800 \mathrm{~km}$ downwind from the fire 


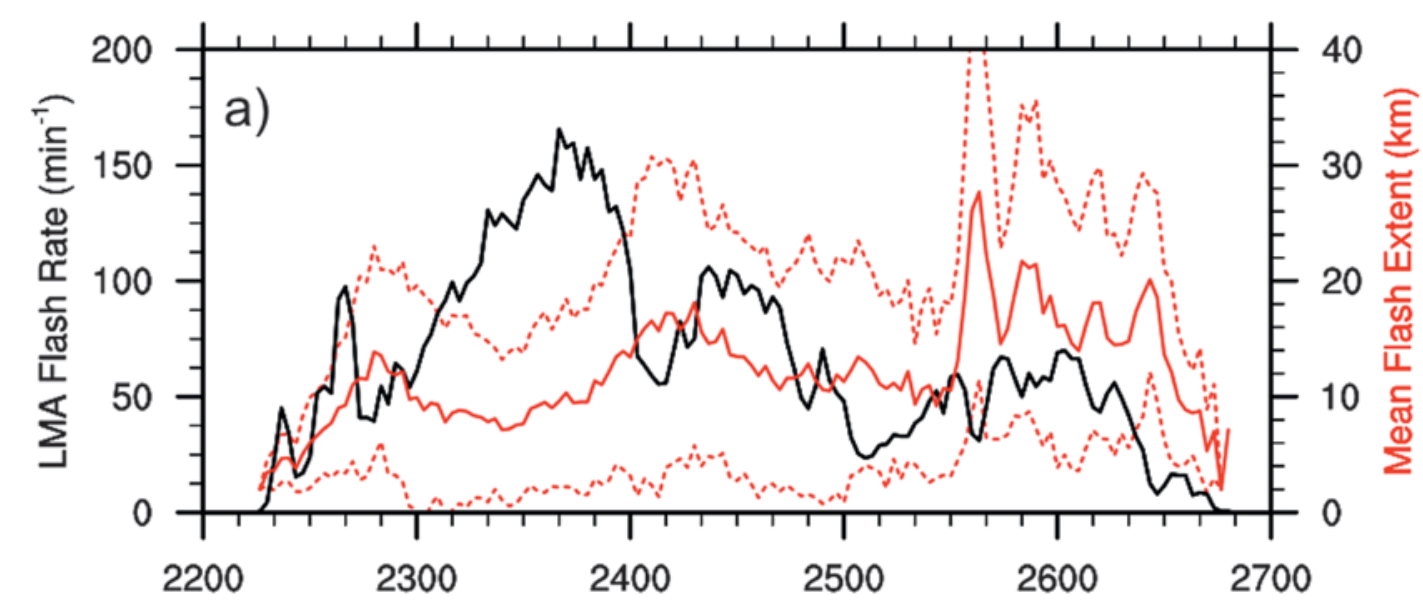

Time (UTC)

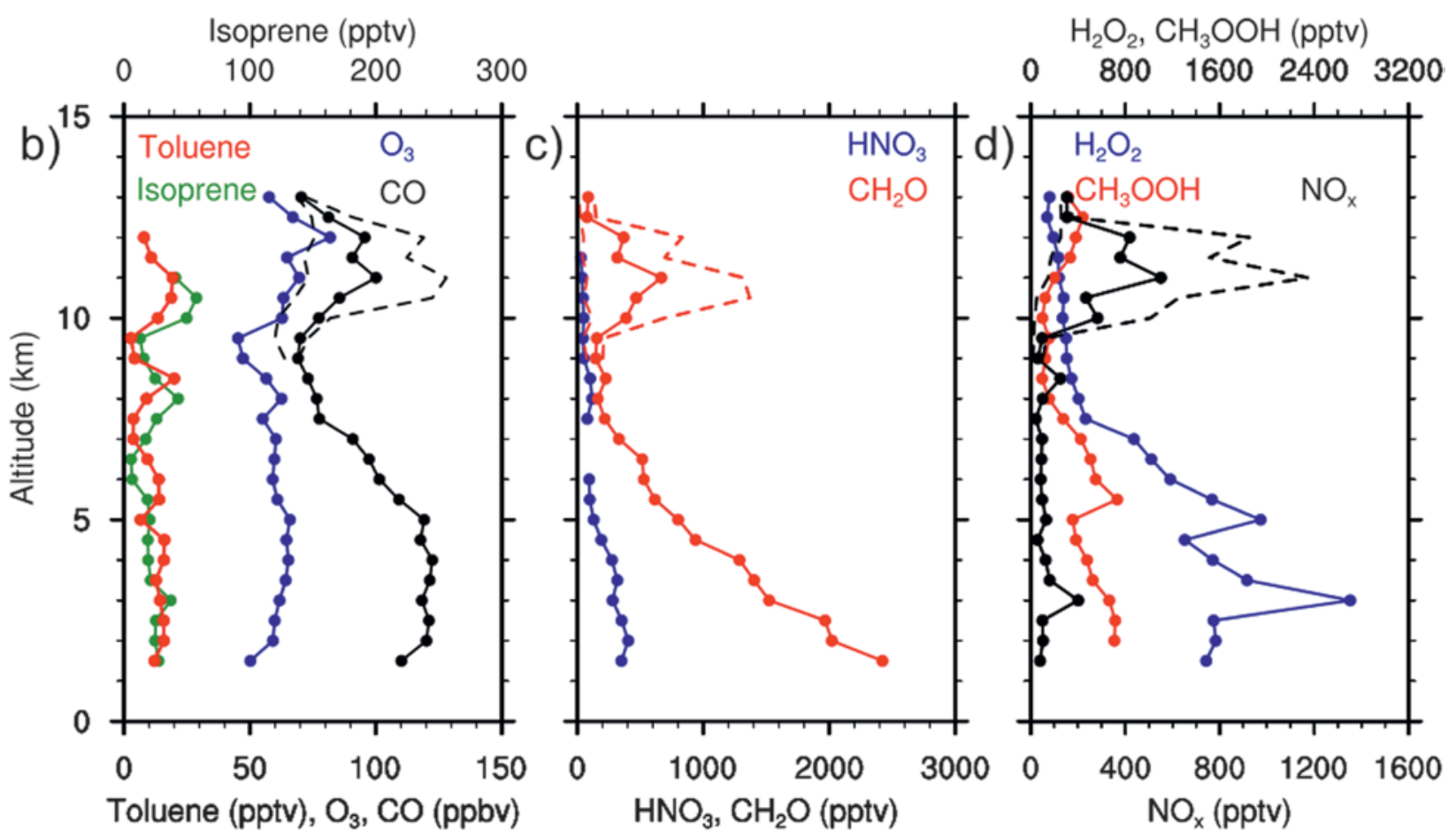

FIG. 16. As in Fig. 10, but for 22 Jun 2012 Colorado region, the DLR Falcon measurements are included, and $\mathbf{O}_{3}$ is plotted using the bottom axis in (b). The smoke plume data are not included in the profiles.

source. The VOC measurements taken by the Falcon in the MCS outflow indicate that portions of the lofted biomass-burning plume were ingested into the MCS. Peak NO mixing ratios measured by the Falcon in the MCS were up to 5 ppbv (average: $2-3$ ppbv). The lastselected Falcon mission was the 12 June 2012 case. The fresh outflow from a squall line over southeast Colorado and southwest Kansas was probed stepwise for a number of cruising levels between 9.5 and $12 \mathrm{~km}$. Again, a pronounced interaction between the convective system, a biomass-burning plume from the High Park fire in Colorado (lofted to $7-10-\mathrm{km}$ altitude), and a stratospheric intrusion (down to
$8 \mathrm{~km}$ ) was observed. At $12 \mathrm{~km}$, lightning-produced $\mathrm{NO}$ was injected into the lower stratosphere $\left(\mathrm{O}_{3}\right.$ mixing ratios around $250 \mathrm{ppbv})$. In this case, $\mathrm{NO}$ mixing ratios averaged 1-2 ppbv, but reached 3 ppbv, which is slightly lower compared to the observations in the 11 June MCS and 30 May supercell case.

SUMMARY. In this study, we show that the DC3 field experiment successfully sampled thunderstorm inflow and outflow regions to estimate entrainment and scavenging efficiencies of trace gases and aerosols. Along with the aircraft measurements, the data collected on storm structure, kinematics, and 

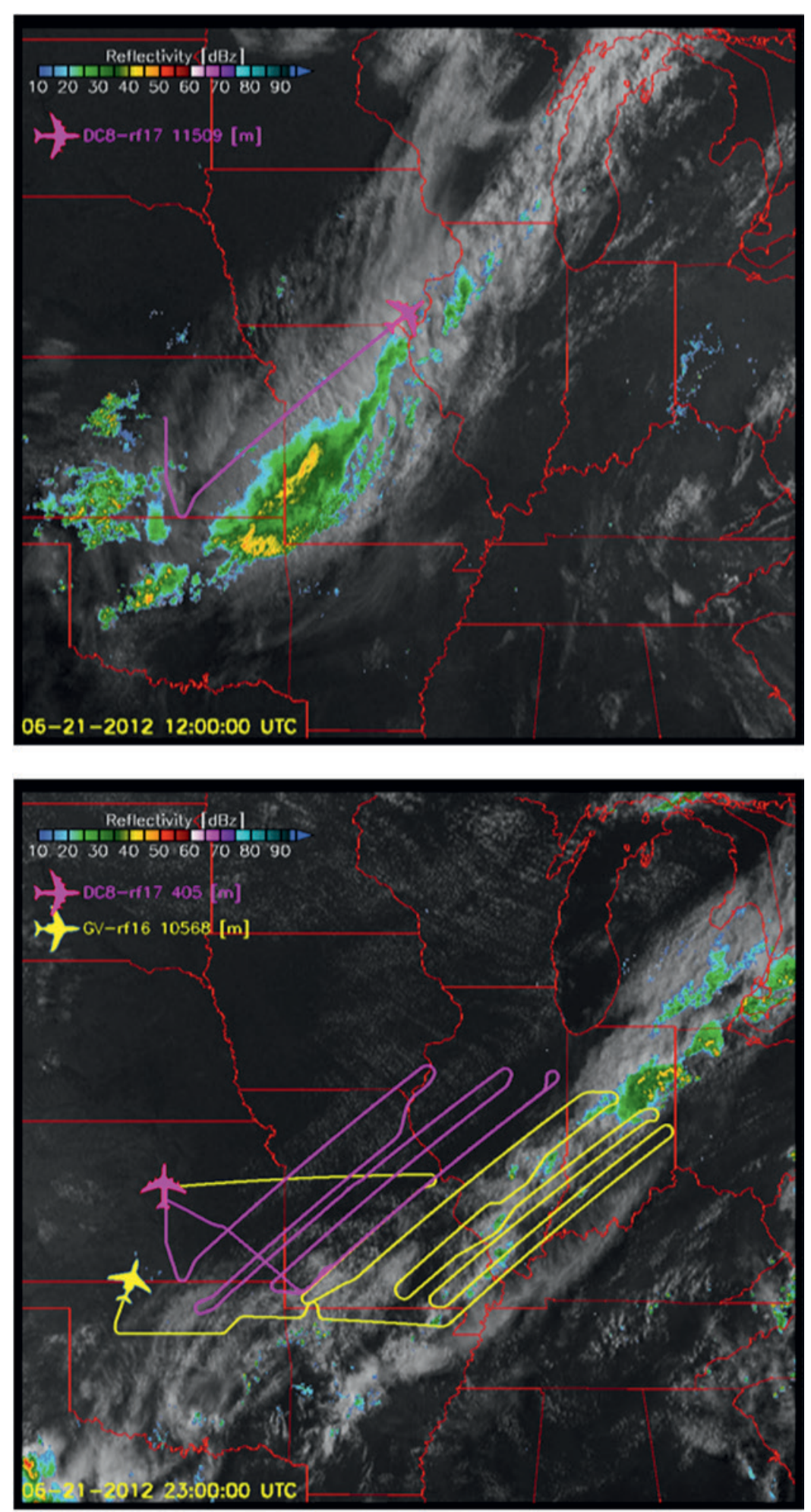

FIG. I7. Composite radar and satellite mosaic at (top) I 200 and (bottom) 2300 UTC 21 Jun 2012 for the dissipating MCS case. The UT air was moving primarily to the east. The pink and yellow lines are the DC-8 and GV aircraft flight legs, respectively, from takeoff of the DC-8 (1058 UTC). The airplane symbols mark the locations of the airplanes at the time of the satellite photo. lightning are providing insight into several objectives. First, by analyzing storm structure, kinematics, and lightning flash rate together, improved or new ways of predicting flash rate based on storm parameters, such as graupel volume, updraft volume, and ice flux, are being investigated. Also being considered are new parameterizations based on flash extent rather than flash rate, similar to Beirle et al. (2014) but in a more in-depth manner, as the DC3 data constitute several hours for each storm sampled. Second, by combining aircraft measurements and lightning data, new estimates of the production of $\mathrm{NO}_{x}$ from lightning are being calculated for several different storms. These estimates can then be placed in context of previous field campaigns from both the midlatitudes and tropics to determine if we can reduce the uncertainty in lightning$\mathrm{NO}_{x}$ production rates and learn whether including other parameters (e.g., lightning flash extent and vertical placement, CAPE, and vertical wind shear) can improve lightning- $\mathrm{NO}_{x}$ production predictions. Third, by combining storm structure and aircraft measurements, connections between cloud microphysical processes (e.g., riming) and trace-gas and aerosol scavenging can be estimated, allowing us to better predict the fate of soluble trace gases and aerosols in storms. A fourth, very interesting finding during DC3 was the effect of thunderstorm dynamics on biomass-burning plumes. In addition to the ingestion of the High Park fire biomass-burning plume into the 22 June 2012 northeast Colorado storm, other cases, primarily observed by the DLR Falcon aircraft, provide evidence of deep convective systems 


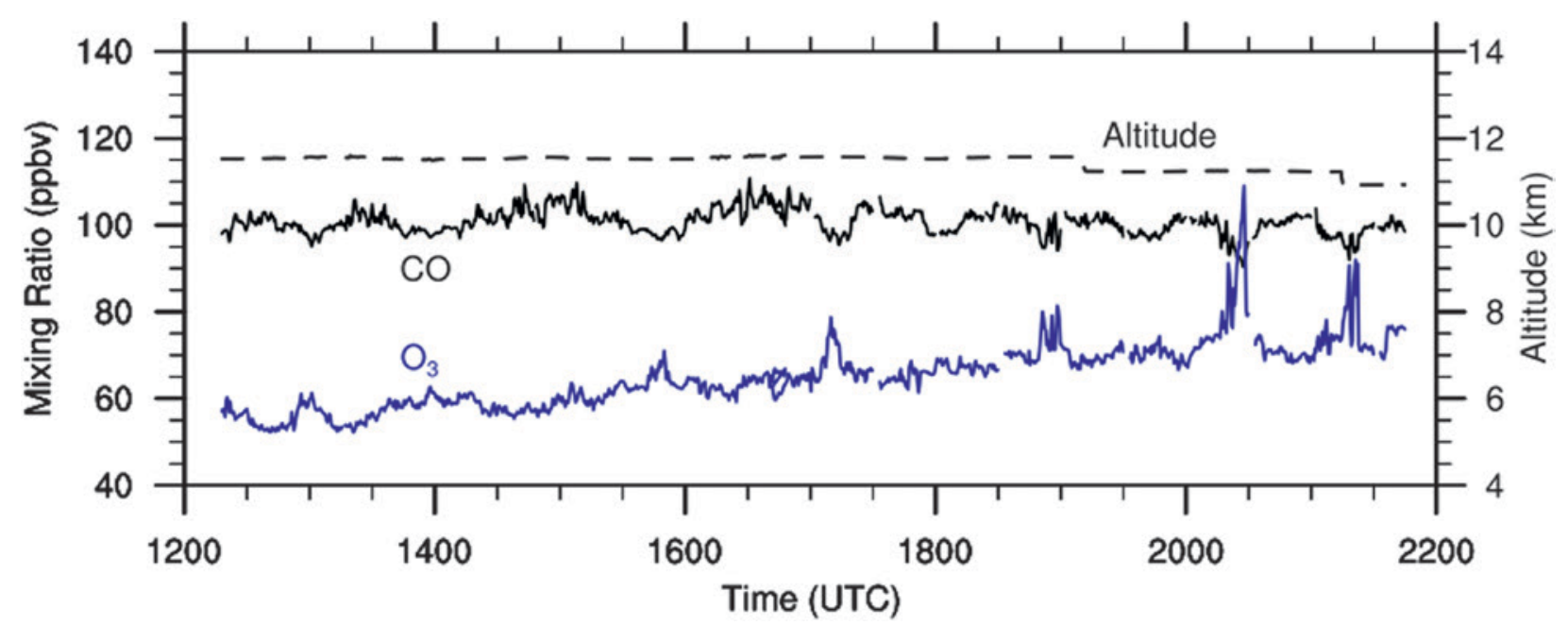

FIG. I8. Time series of altitude, $\mathrm{CO}$, and $\mathrm{O}_{3}$ mixing ratios sampled by the two aircraft during the $2 \mathrm{I}$ Jun 2012 dissipating-MCS case study.

lofting biomass-burning plumes, penetrating into the lowermost stratosphere, and generating stratospheric intrusions along the sides of storms. Additional studies show that the aircraft data, especially the DC- 8 lidar data, provided unique depictions of convectiveinduced mixing between the stratosphere and troposphere, via both direct injections of water into the stratosphere (Homeyer et al. 2014) and wrapping of stratospheric air around the anvil of storms (Pan et al. 2014). The DC3 data are also being analyzed to characterize different anthropogenic and biogenic sources of volatile organic compounds and the tropospheric distribution of aerosol composition, including brown carbon (Liu et al. 2014).

We show that the DC3 campaign successfully sampled the chemical aging of convective outflow either by sampling the storm's outflow a day later or by measuring the convective outflow of an MCS while the storm evolved from a strong active stage to a dissipating stage. Sampling the convective outflow region of a dissipating MCS proved to be a huge success. During this 11 -h time period, the DC- 8 and GV observed increases of $\mathrm{O}_{3}$ by 15-20 ppbv, nitric acid, and other trace gases produced by photochemistry, as well as new particle formation.

The analysis conducted in this study showed that the storms sampled during DC3 had high CAPE and strong vertical wind shear for the Oklahoma-Texas region and low CAPE and low vertical wind shear in the Alabama region, with Colorado storms falling between these extremes. When comparing lightning flash rates with mean flash extents, we often found that when flash rate increased, flash extent decreased and vice versa. The Colorado boundary layer had the lowest influence from biogenic VOCs, while Alabama boundary layer had the highest biogenic VOC mixing ratios. Aerosol loadings in all three regions were typical rural levels or greater. The organic aerosol was often the main PM1 constituent in the boundary layer for all three regions, although Alabama had a larger sulfate contribution than the other two regions.

The DC3 field experiment provides a unique dataset on thunderstorms, including the storm kinematics, physical structure, electrical activity, and the chemical composition of the troposphere as affected by deep convection. The archived data are publicly available at the NCAR Earth Observing Laboratory website (www.eol.ucar.edu/projects/dc3). Future papers on DC3 will report on individual case studies, syntheses of results from several case studies on specific objectives, and numerical simulations of lightning- $\mathrm{NO}_{x}$ production, convective processing of chemical constituents, and chemical aging in convective outflow regions.

ACKNOWLEDGMENTS. DC3 was a complex field campaign coordinating aircraft facilities and groundbased facilities at three different locations. There are many people to thank, each responsible for making the campaign successful. Specifically, we thank the DC-8 HDSP2 teamRushan Gao, Joshua Schwarz, Anne Perring, John Holloway, and Milos Markowic - for the black carbon data used for the PM1 calculation. The National Science Foundation (NSF), the National Aeronautics and Space Administration (NASA), the Deutsches Zentrum für Luft- und Raumfahrt (DLR), and the National Oceanic and Atmospheric Administration (NOAA) are gratefully acknowledged for sponsoring the DC3 field experiment. The field project support provided by NCAR/EOL staff, especially Vidal Salazar and Jim Moore, is greatly appreciated. Data from the field campaign can be found at the NCAR/EOL field projects catalog (www.eol.ucar.edu/projects/dc3/). 


\section{REFERENCES}

Allen, D., K. Pickering, B. Duncan, and M. Damon, 2010: Impact of lightning NO emissions on North American photochemistry as determined using the Global Modeling Initiative (GMI) model. J. Geophys. Res., 115, D22301, doi:10.1029/2010JD014062.

Ancellet, G., J. Leclair de Bellevue, C. Mari, P. Nedelec, A. Kukui, A. Borbon, and P. Perros, 2009: Effects of regional-scale and convective transports on tropospheric ozone chemistry revealed by aircraft observations during the wet season of the AMMA campaign. Atmos. Chem. Phys., 9, 383-411, doi:10.5194 /acp-9-383-2009.

Andrews, E., P. J. Sheridan, and J. A. Ogren, 2011: Seasonal differences in the vertical profiles of aerosol optical properties over rural Oklahoma. Atmos. Chem. Phys., 11, 10661-10676, doi:10.5194 /acp-11-10661-2011.

Avery, M., and Coauthors, 2010: Convective distribution of tropospheric ozone and tracers in the Central American ITCZ region: Evidence from observations during TC4. J. Geophys. Res., 115, D00J21, doi:10.1029/2009JD013450.

Bain, A. L., 2013: Polarimetric Doppler radar and electrical observations of deep moist convection across northern Alabama during the Deep Convective Clouds and Chemistry Experiment. M.S. thesis, Dept. of Atmospheric Sciences, University of Alabama in Huntsville, 148 pp.

Barret, B., and Coauthors, 2010: Impact of West African Monsoon convective transport and lightning $\mathrm{NO}_{x}$ production upon the upper tropospheric composition: A multi-model study. Atmos. Chem. Phys., 10, 5719-5738, doi:10.5194/acp-10-5719-2010.

Barth, M. C., A. L. Stuart, and W. C. Skamarock, 2001: Numerical simulations of the July 10, 1996, Stratospheric-Tropospheric Experiment: Radiation, Aerosols, and Ozone (STERAO)-Deep Convection experiment storm: Redistribution of soluble tracers. J. Geophys. Res., 106, 12381-12400, doi:10.1029/2001JD900139.

—, S.-W. Kim, W. C. Skamarock, A. L. Stuart, K. E. Pickering, and L. E. Ott, 2007a: Simulations of the redistribution of formaldehyde, formic acid, and peroxides in the 10 July 1996 Stratospheric-Tropospheric Experiment: Radiation, Aerosols, and Ozone deep convection storm. J. Geophys. Res., 112, D13310, doi:10.1029/2006JD008046.

_ - and Coauthors, 2007b: Cloud-scale model intercomparison of chemical constituent transport in deep convection. Atmos. Chem. Phys., 7, 4709-4731, doi:10.5194/acp-7-4709-2007.
— , J. Lee, A. Hodzic, G. Pfister, W. C. Skamarock, J. Worden, J. Wong, and D. Noone, 2012: Thunderstorms and upper troposphere chemistry during the early stages of the 2006 North American Monsoon. Atmos. Chem. Phys., 12, 11 003-11 026, doi:10.5194/acp-12-11003-2012.

Beirle, S., W. Koshak, R. Blakeslee, and T. Wagner, 2014: Global patterns of lightning properties derived by OTD and LIS. Nat. Hazards Earth Syst. Sci., 14, 2715-2726, doi:10.5194/nhess-14-2715-2014.

Bertram, T. H., and Coauthors, 2007: Direct measurements of the convective recycling of the upper troposphere. Science, 315, 816-820, doi:10.1126 /science.1134548.

Biggerstaff, M. I., and Coauthors, 2005: The Shared Mobile Atmospheric Research and Teaching radar: A collaboration to enhance research and teaching. Bull. Amer. Meteor. Soc., 86, 1263-1274, doi:10.1175 /BAMS-86-9-1263.

Boccippio, D. J., K. L. Cummins, H. J. Christian, and S. J. Goodman, 2001: Combined satellite- and surface-based estimation of the intracloud-cloudto-ground lightning ratio over the continental United States. Mon. Wea. Rev., 129, 108-122, doi:10.1175/1520-0493(2001)129<0108:CSASBE $>2$ .0.CO;2.

Bruning, E. C., and D. R. MacGorman, 2013: Theory and observations of controls on lightning flash size spectra. J. Atmos. Sci., 70, 4012-4029, doi:10.1175 /JAS-D-12-0289.1.

_-, S. A. Weiss, and K. M. Calhoun, 2014: Continuous variability in thunderstorm primary electrification and an evaluation of inverted-polarity terminology. Atmos. Res., 135-136, 274-284, doi:10.1016/j .atmosres.2012.10.009.

Brunner, D., J. Staehelin, and D. Jeker, 1998: Large-scale nitrogen oxide plumes in the tropopause region and implications for ozone. Science, 282, 1305-1309, doi:10.1126/science.282.5392.1305.

Cai, Y., D. C. Montague, and T. Deshler, 2011: Comparison of measured and calculated scattering from surface aerosols with an average, a size-dependent, and a time-dependent refractive index. J. Geophys. Res., 116, D02202, doi:10.1029/2010JD014607.

Carbone, R. E., J. D. Tuttle, D. A. Ahijevych, and S. B. Trier, 2002: Inferences of predictability associated with warm season precipitation episodes. J. Atmos. Sci., 59, 20332056, doi:10.1175/1520-0469(2002)059<2033:IOPA $\mathrm{WW}>2.0 . \mathrm{CO} ; 2$.

Chatfield, R. B., and P. J. Crutzen, 1984: Sulfur dioxide in remote oceanic air: Cloud transport of reactive precursors. J. Geophys. Res., 89, 7111-7132, doi:10.1029 /JD089iD05p07111. 
Cooper, O. R., and Coauthors, 2006: Large upper tropospheric ozone enhancements above midlatitude North America during summer: In situ evidence from the IONS and MOZAIC ozone monitoring network. J. Geophys. Res., 111, D24S05, doi:10.1029/2006JD007306.

Crawford, J. H., and Coauthors, 2000: Evolution and chemical consequences of lightning-produced $\mathrm{NO}_{x}$ observed in the North Atlantic upper troposphere. J. Geophys. Res., 105, 19 795-19 809, doi:10.1029/2000JD900183.

DeCaria, A. J., K. E. Pickering, G. L. Stenchikov, J. R. Scala, J. L. Stith, J. E. Dye, B. A. Ridley, and P. Laroche, 2000: A cloud-scale model study of lightning-generated $\mathrm{NO}_{\mathrm{x}}$ in an individual thunderstorm during STERAO-A. J. Geophys. Res., 105, 11601-11 616, doi:10.1029/2000JD900033.

,,--- , and L. E. Ott, 2005: Lightninggenerated $\mathrm{NO}_{x}$ and its impact on tropospheric ozone production: A three-dimensional modeling study of a Stratosphere-Troposphere Experiment: Radiation, Aerosols, and Ozone (STERAO-A) thunderstorm. J. Geophys. Res., 110, D14303, doi:10.1029/2004JD005556.

Dickerson, R. R., and Coauthors, 1987: Thunderstorms: An important mechanism in the transport of air pollutants. Science, 235, 460-465, doi:10.1126 /science.235.4787.460.

Dye, J. E., and Coauthors, 2000: An overview of the Stratosphere-Troposphere Experiment: Radiation, Aerosols, and Ozone (STERAO)-Deep Convection experiment with results for the July 10, 1996 storm. J. Geophys. Res., 105, $10023-10045$, doi:10.1029/1999JD901116.

Emmons, L. K., and Coauthors, 2010: Description and evaluation of the Model for Ozone and Related chemical Tracers, version 4 (MOZART-4). Geosci. Model Dev., 3, 43-67, doi:10.5194/gmd-3-43-2010.

Gilmore, M. S., and L. J. Wicker, 2002: Influences of the local environment on supercell cloud-to-ground lightning, radar characteristics, and severe weather on 2 June 1995. Mon. Wea. Rev., 130, 2349-2372, doi:10.1175/1520-0493(2002)130<2349:IOTLEO $>2.0 . \mathrm{CO} ; 2$.

Goodman, S. J., and Coauthors, 2005: The North Alabama Lightning Mapping Array: Recent severe storm observations and future prospects. Atmos. Res., 76, 423-437, doi:10.1016/j.atmosres.2004.11.035.

Hanlon, C. J., G. S. Young, J. Verlinde, A. A. Small, and S. Bose, 2014: Probabilistic forecasting for isolated thunderstorms using a genetic algorithm: The DC3 campaign. J. Geophys. Res. Atmos., 119, 65-74, doi:10.1002/2013JD020195.
Homeyer, C. R., and Coauthors, 2014: Convective transport of water vapor into the lower stratosphere observed during double-tropopause events. J. Geophys. Res. Atmos., 119, $10941-10958$, doi:10.1002/2014JD021485.

Hudman, R. C., and Coauthors, 2007: Surface and lightning sources of nitrogen oxides over the United States: Magnitudes, chemical evolution, and outflow. J. Geophys. Res., 112, D12S05, 10.1029/2006JD007912. _- and Coauthors, 2009: North American influence on tropospheric ozone and the effects of recent emission reductions: Constraints from ICARTT observations. J. Geophys. Res., 114, D07302, doi:10.1029/2008JD010126.

Huntrieser, H., and Coauthors, 2002: Airborne measurements of $\mathrm{NO}_{\mathrm{x}}$, tracer species, and small particles during the European Lightning Nitrogen Oxides Experiment. J. Geophys. Res., 107, 4113, doi:10.1029/2000JD000209.

— over Brazil during TROCCINOX: Airborne measurements in tropical and subtropical thunderstorms and the importance of mesoscale convective systems. Atmos. Chem. Phys., 7, 2987-3013, doi:10.5194 lacp-7-2987-2007.

— Brazilian thunderstorms during TROCCINOX: Implications for $\mathrm{NO}_{x}$ production. Atmos. Chem. Phys., 8, 921-953, doi:10.5194/acp-8-921-2008.

— ning in Hector: First airborne measurements during SCOUT-O3/ACTIVE. Atmos. Chem. Phys., 9, 8377-8412, doi:10.5194/acp-9-8377-2009.

—_, and Coauthors, 2011: Mesoscale convective systems observed during AMMA and their impact on the $\mathrm{NO}_{x}$ and $\mathrm{O}_{3}$ budget over West Africa. Atmos. Chem. Phys., 11, 2503-2536, doi:10.5194 lacp-11-2503-2011.

Jaeglé, L., and Coauthors, 1997: Observed $\mathrm{OH}$ and $\mathrm{HO}_{2}$ in the upper troposphere suggest a major source from convective injection of peroxides. Geophys. Res. Lett., 24, 3181-3184, doi:10.1029/97GL03004.

Johnson, R. H., R. S. Schumacher, J. H. Ruppert Jr., D. T. Lindsey, J. E. Ruthford, and L. Kriederman, 2014: The role of convective outflow in the Waldo Canyon fire. Mon. Wea. Rev., 142, 3061-3080, doi:10.1175 /MWR-D-13-00361.1.

Kuhlman, K. M., C. L. Ziegler, E. R. Mansell, D. R. MacGorman, and J. M. Straka, 2006: Numerically simulated electrification and lightning of the 29 June 2000 STEPS supercell storm. Mon. Wea. Rev., 134, 2734-2757, doi:10.1175/MWR3217.1.

Lang, T. J., and Coauthors, 2004: The Severe Thunderstorm Electrification and Precipitation 
Study. Bull. Amer. Meteor. Soc., 85, 1107-1125, doi:10.1175/BAMS-85-8-1107.

—, S. A. Rutledge, B. Dolan, P. Krehbiel, W. Rison, and D. T. Lindsey, 2014: Lightning in wildfire smoke plumes observed in Colorado during summer 2012. Mon. Wea. Rev., 142, 489-507, doi:10.1175 /MWR-D-13-00184.1.

Li, Q., and Coauthors, 2005: North American pollution outflow and the trapping of convectively lifted pollution by upper-level anticyclone. J. Geophys. Res., 110, D10301, doi:10.1029/2004JD005039.

Liu, J., and Coauthors, 2014: Brown carbon in the continental troposphere. Geophys. Res. Lett., 41, 2191-2195, doi:10.1002/2013GL058976.

MacGorman, D. R., W. D. Rust, P. R. Krehbiel, W. Rison, E. C. Bruning, and K. Wiens, 2005: The electrical structure of two supercell storms during STEPS. Mon. Wea. Rev., 133, 2583-2607, doi:10.1175 /MWR2994.1.

— - and Coauthors, 2008: TELEX: The Thunderstorm Electrification and Lightning Experiment. Bull. Amer. Meteor. Soc., 89, 997-1013, doi:10.1175 /2007BAMS2352.1.

—, I. R. Apostolakopoulos, N. R. Lund, N. W. S. Demetriades, M. J. Murphy, and P. R. Krehbiel, 2011: The timing of cloud-to-ground lightning relative to total lightning activity. Mon. Wea. Rev., 139, 3871-3886, doi:10.1175/MWR-D-11-00047.1.

Pan, L. L., and Coauthors, 2014: Thunderstorms enhance tropospheric ozone by wrapping and shedding stratospheric air. Geophys. Res. Lett., 41, 7785-7790, doi:10.1002/2014GL061921.

Pickering, K. E., A. M. Thompson, R. R. Dickerson, W. T. Luke, D. P. McNamara, J. P. Greenberg, and P. R. Zimmerman, 1990: Model calculations of tropospheric ozone production potential following observed convective events. J. Geophys. Res., 95, 14049-14062, doi:10.1029/JD095iD09p14049.

— , and Coauthors, 1996: Convective transport of biomass burning emissions over Brazil during TRACE A. J. Geophys. Res., 101, 23 993-24 012, doi:10.1029/96JD00346.

Pierce, R. B., and Coauthors, 2007: Chemical data assimilation estimates of continental U.S. ozone and nitrogen budgets during the Intercontinental Chemical Transport Experiment-North America. J. Geophys. Res., 112, D12S21, doi:10.1029/2006JD007722.

Qie, X., R. Toumi, and Y. Zhou, 2003: Lightning activity on the central Tibetan Plateau and its response to convective available potential energy. Chin. Sci. Bull., 48, 296-299.

Ridley, B., J. G. Walega, J. E. Dye, and F. E. Grahek, 1994: Distributions of $\mathrm{NO}, \mathrm{NO}_{\mathrm{x}}, \mathrm{NO}_{\mathrm{y}}$, and $\mathrm{O}_{3}$ to $12 \mathrm{~km}$ altitude during the summer monsoon season over New Mexico. J. Geophys. Res., 99, 25 519-25 534, doi:10.1029/94JD02210.

- , and Coauthors, 2004a: Convective transport of reactive constituents to the tropical and mid-latitude tropopause region: I. Observations. Atmos. Environ., 38, 1259-1274, doi:10.1016/j .atmosenv.2003.11.038.

— , and Coauthors, 2004b: Florida thunderstorms: A faucet of reactive nitrogen to the upper troposphere. J. Geophys. Res., 109, D17305, doi:10.1029/2004JD004769.

Rison, W., R. J. Thomas, P. R. Krehbiel, T. Hamlin, and J. Harlin, 1999: A GPS-based three-dimensional lightning mapping system: Initial observations in central New Mexico. Geophys. Res. Lett., 26, 3573-3576, doi:10.1029/1999GL010856.

Romine, G., C. Schwartz, J. Berner, K. R. Smith, C. Snyder, J. L. Anderson, and M. Weisman, 2014: Representing forecast error in a convection-permitting ensemble system. Mon. Wea. Rev., 142, 4519-4541, doi:10.1175/MWR-D-14-00100.1.

Rust, W. D., and D. R. MacGorman, 2002: Possibly inverted-polarity electrical structures in thunderstorms during STEPS. Geophys. Res. Lett., 29, doi:10.1029/2001GL014303.

_ , T. C. Marshall, M. Stolzenburg, and F. Fitzgibbon, 1999: Test of a GPS radiosonde in thunderstorm electrical environments. J. Atmos. Oceanic Technol., 16, 550-560, doi:10.1175/1520-0426(1999)016<0550:TO AGRI>2.0.CO;2.

— , and Coauthors, 2005: Inverted-polarity electrical structures in thunderstorms in the Severe Thunderstorm Electrification and Precipitation Study (STEPS). Atmos. Res., 76, 247-271, doi:10.1016/j .atmosres.2004.11.029.

Schumann, U., and H. Huntrieser, 2007: The global lightning-induced nitrogen oxides source. Atmos. Chem. Phys., 7, 3823-3907, doi:10.5194 /acp-7-3823-2007.

Schwartz, C., G. Romine, K. Smith, and M. Weisman, 2014: Characterizing and optimizing precipitation forecasts from a convection-permitting ensemble initialized by a mesoscale ensemble Kalman filter. Wea. Forecasting, 29, 1295-1318, doi:10.1175 /WAF-D-13-00145.1.

Singh, H. B., and Coauthors, 2007: Reactive nitrogen distribution and partitioning in the North American troposphere and lowermost stratosphere. J. Geophys. Res., 112, D12S04, doi:10.1029/2006JD007664.

Snow, J. A., B. G. Heikes, H. Shen, D. W. O’Sullivan, A. Fried, and J. Walega, 2007: Hydrogen peroxide, methyl hydroperoxide, and formaldehyde over North 
America and the North Atlantic. J. Geophys. Res., 112, D12S07, doi:10.1029/2006JD007746.

Stohl, A., C. Forster, A. Frank, P. Seibert, and G. Wotawa, 2005: Technical note: The Lagrangian particle dispersion model FLEXPART version 6.2. Atmos. Chem. Phys., 5, 2461-2474, doi:10.5194/acp-5-2461-2005.

Tessendorf, S. A., K. C. Wiens, and S. A. Rutledge, 2007: Radar and lightning observations of the 3 June 2000 electrically inverted storm from STEPS. Mon. Wea. Rev., 135, 3665-3681, doi:10.1175/2006MWR1953.1.

Weiss, S. A., W. D. Rust, D. R. MacGorman, E. C. Bruning, and P. R. Krehbiel, 2008: Evolving complex electrical structures of the STEPS 25 June 2000 multicell storm. Mon. Wea. Rev., 136, 741-756, doi:10.1175/2007MWR2023.1.

Wiens, K. C., S. A. Rutledge, and S. A. Tessendorf, 2005: The 29 June 2000 supercell observed during STEPS.
Part II: Lightning and charge structure. J. Atmos. Sci., 62, 4151-4177, doi:10.1175/JAS3615.1.

Williams, E. R., S. G. Geotis, N. Renno, S. A. Rutledge, E. Rasmussen, and T. Rickenbach, 1992: A radar and electrical study of tropical "hot towers." J. Atmos. Sci., 49, 1386-1395, doi:10.1175/1520-0469(1992)049<1386:AR $\mathrm{AESO}>2.0 . \mathrm{CO} ; 2$.

—, V. Mushtak, D. Rosenfeld, S. Goodman, and D. Boccippio, 2005: Thermodynamic conditions favorable to superlative thunderstorm updraft, mixed phase microphysics and lightning flash rate. Atmos. Res., 76, 288-306, doi:10.1016/j.atmosres.2004.11.009.

Zhang, R. Y., X. X. Tie, and D. W. Bond, 2003: Impacts of anthropogenic and natural $\mathrm{NO}_{\mathrm{x}}$ sources over the U.S. on tropospheric chemistry. Proc. Natl. Acad. Sci. USA, 100, 1505-1509, doi:10.1073/pnas.252763799.

\section{NEW FROM AMS BOOKS!}

\section{"A thoughtful analysis of actions that we need to take to reduce the impacts of extreme weather... a must-read for everyone with an interest in the weather and climate." \\ - FRANKLIN W. NUTTER, \\ President, Reinsurance Association of America}

\section{Living on the Real World: How Thinking and Acting Like Meteorologists Will Help Save the Planet}

WILLIAM H. HOOKE

Meteorologists sift through a deluge of information to make predictions every day. Instead of being overwhelmed by the data and possibilities, they focus on small bits of information while using frequent collaboration to make decisions. With climate change a reality, William $\mathrm{H}$. Hooke suggests we look to the way meteorologists operate as a model for how we can solve the twenty-first century's most urgent environmental problems. 


\section{Radar and Atmospheric Science: A Collection of Essays in Honor of David Atlas}

Edited by Roger M. Wakimoto and Ramesh Srivastava

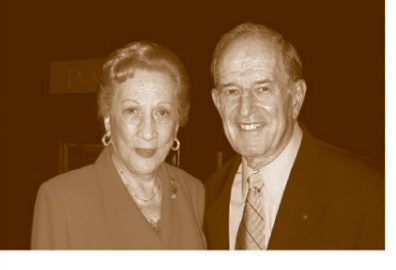

This monograph pays tribute to one of the leading scientists in meteorology, Dr. David Atlas. In addition to profiling the life and work of the acknowledged "Father of Radar Meteorology" this collection highlights many of the unique contributions he made to the understanding of the forcing and organization of convective systems, observation and modeling of atmospheric turbulence and waves, and cloud microphysical properties, among many other topics. It is hoped that this text will inspire the next generation of radar meteorologists, provide an excellent resource for scientists and educators, and serve as a historical record of the gathering of scholarly contributions honoring one of the most important meteorologists of our time.

Radar and Atmospheric Science:

A Collection of Essays in Honor of David Atlas

Aug 2003. Meteorological Monograph Series, Vol. 30, No. 52; 270 pp, hardbound; ISBN 1-878220-57-8; AMS code MM52.

Price $\$ 75.00$ list $\$ 55.00$ member

To place an order point your Web browser to www.ametsoc.org/amsbookstore

RADAR ANU ATMOSPHERIC SCIENCE:
A COLLECTION OF ESSAYS INHONOR OF

DAVID ATI.AS

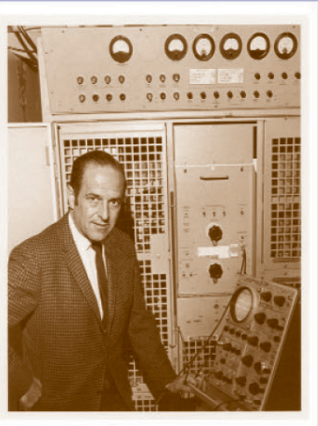

